\title{
Effects of water-sediment interaction and irrigation practices on iodine enrichment in shallow groundwater
}

\author{
Junxia $\mathrm{Li}^{\mathrm{a}}$, Yanxin Wang ${ }^{\mathrm{a}, *}$, Xianjun Xie ${ }^{\mathrm{a}}$, Donald J. DePaolo ${ }^{\mathrm{b}, \mathrm{c}}$
}

\begin{abstract}
High iodine concentrations in groundwater have caused serious health problems to the local residents in the Datong basin, northern China. To determine the impact of water-sediment interaction and irrigation practices on iodine mobilization in aquifers, isotope $\left({ }^{2} \mathrm{H},{ }^{18} \mathrm{O}\right.$ and $\left.{ }^{87} \mathrm{Sr} /{ }^{86} \mathrm{Sr}\right)$ and hydrogeochemical studies were conducted. The results show that groundwater iodine concentrations vary from 14.4 to $2180 \mu \mathrm{g} / \mathrm{L}$, and high iodine groundwater $(>150 \mu \mathrm{g} / \mathrm{L})$ mainly occurs in the central area of the Datong basin. Sediment iodine content is between $<0.01$ and $1.81 \mathrm{mg} / \mathrm{kg}$, and the co-occurrence of high iodine and high DOC/TOC concentrations of groundwater and sediment samples
\end{abstract}


24 in the deeper aquifer indicates that the sediment enriched in iodine and organic matter

25 acts as the main source of groundwater iodine. The ${ }^{87} \mathrm{Sr} /{ }^{86} \mathrm{Sr}$ values and groundwater

26 chemistry suggest that aluminosilicate hydrolysis is the dominant process controlling

27 hydrochemical evolution along groundwater flowpath, and the degradation of

28 TOC/iodine-rich sediment mediated by microbes potentially triggers the iodine release

29 from the sediment into groundwater in the discharge area. The vertical stratification of

30 groundwater ${ }^{18} \mathrm{O}$ and ${ }^{2} \mathrm{H}$ isotope reflects the occurrence of a vertical mixing process

31 driven by periodic surface irrigation. The vertical mixing could change the redox

32 potential of shallow groundwater from sub-reducing to oxidizing condition, thereby

33 affecting the iodine mobilization in shallow groundwater. It is postulated that the extra

34 introduction of organic matter and $\mathrm{O}_{2} / \mathrm{NO}_{3} / \mathrm{SO}_{4}$ could accelerate the microbial activity

35 due to the supplement of high ranking electron acceptors and promote the iodine release

36 from the sediment into shallow groundwater.

37

38 Keywords: Vertical mixing; Water-sediment interaction; Groundwater; Iodine; Datong

39 basin

40

\section{1. Introduction}

42 Iodine is an essential micronutrient for human beings, but excessive intake causes

43 health problems, including goiter, cretinism, thyroid autoimmunity and even thyroid

44 cancers. Cases of iodine enrichment in groundwater have been widely reported in coastal

45 area, such as Japan (Shimamoto et al., 2011), Denmark (Andersen et al., 2002), North

46 China Plain (Zhang et al., 2013a), as well as in inland basins, such as La Pampa plain 
47 (Smedley et al., 2002), Datong basin (Li et al., 2013) and Taiyuan basin (Tang et al., 48 2013). In areas affected by waterborne iodine poisoning, groundwater typically provides

49 the dominant source for water supply, therefore understanding the mechanisms of iodine 50 mobilization in the source aquifers is critical both for sustainable water resource 51 management and for effective actions to diminish iodine poisoning.

52 Due to the absorption capability of iodine, natural organic matter is commonly 53 considered as the primary pool of solid iodine (Hansen et al., 2011; Shetaya et al., 2012;

$54 \mathrm{Xu}$ et al., 2012). And the involved biogeochemical processes have been consequently 55 regarded as the dominant control on the iodine cycle in aquatic environments (Amachi et 56 al., 2007; Amachi et al., 2005). The behavior and speciation states of iodine depend 57 mainly on the redox condition of the groundwater environment ( $\mathrm{Li}$ et al., 2014; Otosaka 58 et al., 2011). Changes of redox condition from oxidizing to reducing promote the 59 reduction of iodate or organic-iodine, thereby lowering the absorption ability of iodine 60 onto the organic matter or metal oxides and hydroxides (Dai et al., 2009; Hu et al., 2012;

61 Shimamoto et al., 2010; Xu et al., 2015). In the Datong basin, high iodine concentrations 62 up to $1890 \mu \mathrm{g} / \mathrm{L}$ have been detected in the shallow groundwater from the discharge area 63 where the groundwater condition is characterized by lower flow rate, long residence time 64 and (sub)reducing conditions ( $\mathrm{Li}$ et al., 2014; Li et al., 2013). Recently, periodic 65 irrigation practices using deep groundwater and surface water as the irrigation sources 66 have the potential to change the shallow groundwater environment through water table 67 fluctuation ( $\mathrm{Li}$ et al., 2016). The variation of the groundwater evironment might further 68 influence the geochemical cycling of iodine in the shallow aquifer due to the sensitivity 
69 of iodine species to the redox potential of groundwater system. However, the effects of

70 irrigation practices on iodine mobilization are still not well studied.

71 Stable isotope signatures $\left({ }^{2} \mathrm{H},{ }^{18} \mathrm{O}\right.$, and $\left.{ }^{87} \mathrm{Sr} /{ }^{86} \mathrm{Sr}\right)$ have been recently documented to

72 be useful proxies for tracing groundwater recharge sources and flowpaths in

73 meteorological, hydrological, and hydrogeological systems (e.g. (Peng et al., 2010b;

74 Schiavo et al., 2009; Stichler et al., 2008)). The comparison of $\delta^{18} \mathrm{O}$ and $\delta^{2} \mathrm{H}$

75 compositions of water samples to Global Meteoric Water Line (GMWL) reported by

76 Craig (1961) can provide valuable information on water origin and regional hydrological

77 setting (Peng et al., 2012). Strontium isotope signatures could provide an opportunity to

78 trace the major contributing sources to the ultimate geochemical composition of the

79 groundwater due to its advantage of hardly being fractionated by phase separation,

80 evaporation or biological assimilation (Sánchez et al., 2010; Skrzypek et al., 2013). This

81 study, therefore, aims to identify the effects of water-sediment interaction and irrigation

82 practices on iodine enrichment in shallow aquifers of the Datong basin based on $\delta^{2} \mathrm{H}$,

$83 \delta^{18} \mathrm{O}$ and ${ }^{87} \mathrm{Sr} /{ }^{86} \mathrm{Sr}$ signatures and hydrogeochemical features of natural high iodine 84 groundwater.

$86 \quad 2$. Study area

\section{$87 \quad 2.1$ Geological setting}

88 The Datong basin, located in northern China, is a NW-SE oriented Cenozoic rifted 89 basin, which experienced multiple periods of lithospheric extensions and associated 90 volcanism since the late Pleistocene (Chen et al., 1992). The active Cenozoic volcanism 91 mainly occurs in the northern part of the basin. Subsidence associated with rifting 
92 resulted in the formation and development of a lake that persisted from the Miocene to

93 the Quaternary. As a result of this extended history, the Quaternary lacustrine sediments

94 of the Datong basin commonly have high contents of humic substances (Li et al., 2013).

95 Due to the variations in sedimentation rate, the thickness of Cenozoic sediments in the

96 south and north centers of the Datong Basin are quite different: $3500 \mathrm{~m}$ and $1500 \mathrm{~m}$,

97 respectively (Cheng, 1983). The Sanggan River system and piedmont alluvial fans

98 developed over the basin-scale in the Last Glacial (about $70 \mathrm{ka}$ ) (Wang et al., 2008; Zhou

99 et al., 1991). Currently, in most of the Datong Basin, the lacustrine strata are overlain by

100 alluvial plain, pluvial fans, and wind-blown deposits that accumulated under arid/semi-

101 arid glacial period conditions (Gu et al., 2015).

102 The major types of rocks and sediments in the Datong basin can be classified into 103 four groups (Li et al., 2009; Xie et al., 2011): (1) Archean metamorphic complex 104 (granites and gneiss with greenstone terrain) in the east margin (Heng Mountain); (2) 105 Cambrian to Ordovician limestone and dolomite with clastic rocks, mainly located in the 106 southwest margin (Hongshou Mountain), (3) Carboniferous to Permian coal-bearing 107 clastic rocks in the northwest margin containing varying amounts of inter-bedded 108 sandstone, siltstone and shale, and (4) late Pliocene to Holocene basin sediments (alluvial 109 and fluvial gravel, sand and silt) (Fig. 1).

110

\section{$111 \quad 2.2$ Hydrological setting}

112 With an arid/semi-arid climate, the annual average precipitation of the Datong basin 113 is between 225 and $400 \mathrm{~mm}$ with 75 to $85 \%$ of rainfall occurring in July and August, and 114 annual evaporation is above $2000 \mathrm{~mm}$. Groundwater table changes from $>20 \mathrm{~m}$ below the 
115 land surface in the margin area to approximately $2 \sim 3 \mathrm{~m}$ in the central area with 116 fluctuations caused by irrigation activities (Li et al., 2016). Except for some poor saline

117 soils in the central area, most of the soils in the Datong basin have been cultivated for 118 agriculture for centuries. Two upstream reservoirs and many ditches were built for 119 irrigation practices which are conducted in March and September each year. As a result, 120 the Sanggan River, as the main surface water, has temporary water flow only after intense 121 rainfall events or between irrigation periods.

122 Basin-scale groundwater flow is generally in accordance with the topography from 123 the northwest piedmont to the southeast area and from the basin margin to the central 124 area (Xie et al., 2013). Generally, the Quaternary aquifers in the Datong basin can be 125 divided into three parts with depths: upper $(<50 \mathrm{~m})$, intermediate $(50 \sim 160 \mathrm{~m})$, and lower 126 (> $160 \mathrm{~m}$ ) aquifers (Guo and Wang, 2004). The upper aquifer consists of inter-bedded 127 coarse sand, gravel and clay formed in late Pleistocene and Holocene, and is mainly 128 recharged by vertical infiltration of meteoric and/or irrigation water. The intermediate 129 aquifer was separated into several parts by the multiple clay units in brown, gray or dark 130 colors, and generally contains several 2 10 m thick aquifers which are the main source of 131 drinking and irrigation water for residents. The lower aquifer is made up of fine sand and 132 silt formed in the early Pleistocene and Pliocene, and has the lowest specific capacity in 133 comparison to the upper and intermediate aquifers. The laterally flowing groundwater 134 from the fractured bedrock along the basin margins are the main recharge sources for the 135 intermediate and lower aquifers. Evapotranspiration and artificial extraction for drinking 136 and irrigation proposes are the two major forms of groundwater discharge at the Datong 
137 basin. The depth for groundwater sampling in this study varies from 16 to $100 \mathrm{~m}$ in the 138 upper and intermediate aquifers (Table 1).

140 3. Methods

$141 \quad 3.1$ Sampling and chemical analysis

142 A total of 29 water samples (26 groundwater, 2 surface water and 1 rain sample) 143 were collected from Datong basin in August 2013 (Fig. 1 and Table 1). Prior to sampling 144 groundwater, the wells were purged for at least 10 min using a high flow-rate pump. 145 Total dissolved solid (TDS), redox potential (Eh), temperature (T) and $\mathrm{pH}$ were 146 monitored in situ using HACH Instruments' portable meters. Samples were collected in $147 \mathrm{HNO}_{3}$-washed polyethylene containers after infiltration using $0.45 \mu \mathrm{m}$ membranes. The 148 samples for cation and trace element analysis were acidified using ultra-purified $\mathrm{HNO}_{3}$ to $149 \mathrm{pH}<2$, and samples for anion, dissolved organic carbon (DOC), total iodine and $\mathrm{Sr}$ 150 isotope analysis were stored in $50 \mathrm{~mL}$ polyethylene bottles directly after sampling. The 151 samples for hydrogen and oxygen isotope analysis were collected without filtration.

152 Alkalinity measurements were performed using a titration method within $24 \mathrm{~h}$ after 153 sampling. Groundwater DOC concentrations were measured using the high-temperature 154 catalytic combustion method with a TOC analyzer after inorganic carbon was removed 155 using dilute $\mathrm{HCl}(2 \mathrm{~mol} / \mathrm{L})$ (Multi N/C 3100 TOC; Analytik Jena AG). Anions were 156 analyzed using Ion Chromatography (IC) (Metrohm 761 Compact). Cation and trace 157 elements including total iodine concentration were determined using ICP-AES (IRIS 158 Intrepid II XSP) and ICP-MS (PerkinElmer ELAN DRC-e), respectively. An agreement 
159 of below $\pm 5 \%$ error was fulfilled in laboratory hydrochemical analysis. Charge balance 160 errors for all groundwater samples were below 9\% (QA-QC).

161 A $122 \mathrm{~m}$ depth borehole named DXZ was drilled in the central part of Datong basin 162 in September 2012 and sediment samples were collected using capped PVC pipe and 163 stored at $4^{\circ} \mathrm{C}$ until analysis (Li et al., 2013) (Fig. 1). Three bedrock samples were 164 collected and stored in zip lock bags. A subset of sediment and rock samples was air165 dried and crushed to pass through $0.125 \mathrm{~mm}$ sieves for further analysis. Sediment TOC 166 was determined using an element analyzer (Vario TOC, Elementar). Major elements 167 compositions $\left(\mathrm{SiO}_{2}, \mathrm{Fe}_{2} \mathrm{O}_{3}, \mathrm{TiO}_{2}, \mathrm{Al}_{2} \mathrm{O}_{3}, \mathrm{CaO}, \mathrm{P}_{2} \mathrm{O}_{5}, \mathrm{MgO}\right.$ and $\left.\mathrm{MnO}\right)$ were determined 168 using an XRF spectrometer (model RIX2100; Rigaku, the Wood lands, TX). Sediment 169 iodine was extracted using $10 \%$ dilute ammonia after being pressurized for 170 decomposition at $190{ }^{\circ} \mathrm{C}$ for $19 \mathrm{~h}$, which was developed and tested by Bing et al. (2004) 171 and Xu et al. (2010), respectively, and further measured using ICP-MS (PerkinElmer 172 ELAN DRC-e) with the average error less than $\pm 5 \%$. All the chemical analysis work 173 above was done at the State Key Laboratory of Biogeology and Environmental Geology, 174 China University of Geosciences, Wuhan.

\section{$176 \quad 3.2$ Isotope analysis}

$177 \delta \delta^{18} \mathrm{O}$ and $\delta^{2} \mathrm{H}$ signatures of all water samples were measured in China University of 178 Geosciences (Wuhan) using Finnigan MAT 253 mass spectrometer and reported in 179 standard delta notation relative to V-SMOW. Oxygen isotopes were determined via 180 equilibration with $\mathrm{H}_{2} \mathrm{O}-\mathrm{CO}_{2}$ at $25^{\circ} \mathrm{C}$ for $24 \mathrm{~h}$ and analyzed by continuous-flow mass 181 spectrometry using a Thermo Finnigan Gas Bench. Hydrogen isotopes were measured 
182 using an automated Finnigan MAT H/Device by reacting with $\mathrm{Cr}$ at $850^{\circ} \mathrm{C}$. Precisions for

183 both $\delta^{2} \mathrm{H}$ and $\delta^{18} \mathrm{O}$ are $\pm 1.0 \%$ and $\pm 0.1 \%$, respectively.

184 Strontium isotope signatures of 25 water samples (23 groundwater and 2 surface 185 water), 7 sediments and 3 rocks were measured using thermal ionization mass 186 spectrometry (TIMS) at the Center for Isotope Geochemistry, University of California, 187 Berkeley. Isotope separations for approximately $1 \mu \mathrm{g}$ strontium were performed on ion 188 exchange columns using Eichrom Sr Spec resin. $100 \mathrm{ng}$ of separated Sr (in a solution of $1893 \mathrm{~N} \mathrm{HNO}_{3}$ ) are loaded with $\mathrm{TaCl}$ onto a single Re filament. During the analysis period of 190 our samples, the composition and reproducibility of the NBS 987 strontium standard was $1910.71024 \pm 1 .{ }^{87} \mathrm{Sr} /{ }^{86} \mathrm{Sr}$ ratios were reported with 2 s.d. internal errors.

193 4. Results

194 4.1 Hydrochemistry, $\delta^{2} \mathrm{H}, \delta^{18} \mathrm{O}$ and ${ }^{87} \mathrm{Sr} /{ }^{86} \mathrm{Sr}$ signatures of water samples 195 4.1.1 Groundwater Chemistry

196 The physio-chemical parameters of water samples are listed in Table 1. The 197 groundwater TDS had a range of $298.1 \sim 10150 \mathrm{mg} / \mathrm{L}$ (median value: $1057 \mathrm{mg} / \mathrm{L}$ ), and the 198 high TDS values mostly occur in shallow groundwater with depth less than $25 \sim 30 \mathrm{~m}$. The 199 groundwater $\mathrm{pH}$ was near-neutral to weak alkaline (7.26 9.28). Concentrations of 200 groundwater $\mathrm{HCO}_{3}$ were very high, reaching up to $2120 \mathrm{mg} / \mathrm{L}$ with a median value of $201635 \mathrm{mg} / \mathrm{L}$. Groundwater $\mathrm{Na}$ concentrations ranged from 9.2 to $1960 \mathrm{mg} / \mathrm{L}$ with the 202 median value of $429 \mathrm{mg} / \mathrm{L}$, and Ca concentrations were between 2.86 and $454 \mathrm{mg} / \mathrm{L}$. Na$203 \mathrm{HCO}_{3}$ water is the dominant type of groundwater, and the $\mathrm{Ca}-\mathrm{HCO}_{3}$ type water mainly 204 occurs in the east margin of the study area. Additionally, high $\mathrm{NO}_{3}$ concentration up to 
$205897 \mathrm{mg} / \mathrm{L}$ was detected in shallow groundwater, which might be related to agricultural 206 activity.

207 The iodine concentration in groundwater ranged from 14.4 to $2180 \mu \mathrm{g} / \mathrm{L}$, with $48 \%$ 208 of the samples failing to meet the national standard for drinking water of China (150 $209 \mu \mathrm{g} / \mathrm{L})$. As reported in our previous studies, high iodine groundwater (> $150 \mu \mathrm{g} / \mathrm{L})$ occurs 210 in both shallow and deep aquifers of the Datong basin (Fig. 2) (Li et al., 2014; Li et al., 211 2013). By contrast, the two upstream reservoir water samples had relatively lower iodine 212 concentrations (64.2 and $90.3 \mu \mathrm{g} / \mathrm{L}$, respectively).

\subsubsection{Hydrogen and oxygen isotope signatures}

215 The results of isotope signatures $\left({ }^{2} \mathrm{H},{ }^{18} \mathrm{O}\right.$ and $\left.{ }^{87} \mathrm{Sr} /{ }^{86} \mathrm{Sr}\right)$ of water samples from the 216 Datong basin are presented in Table 1. The $\delta^{2} \mathrm{H}$ and $\delta^{18} \mathrm{O}$ values of groundwater ranged 217 from -90.2 to $-55.6 \%$ and from -12.1 to $-6.5 \%$, respectively. All groundwater can be 218 divided into two groups according to the $\delta^{2} \mathrm{H}$ and $\delta^{18} \mathrm{O}$ values: Group I is characterized 219 by enrichment of light isotope with the $\delta^{2} \mathrm{H}$ and $\delta^{18} \mathrm{O}$ ranging from -90.2 to $-82.9 \%$ and 220 from -12.1 to $-10.7 \%$, respectively; Group II, by contrast, has heavier hydrogen and 221 oxygen isotope signatures, changing between -76.0 and -55.6\%o and between -10.1 and $2226.5 \%$, respectively. The distinctive hydrogen and oxygen isotope signatures of these two 223 group samples might reflect the impact of vertical mixing processes in the study area.

224 The two upstream reservoir water samples are characterized by heavier $\delta^{2} \mathrm{H}$ and $225 \delta^{18} \mathrm{O}$ values (mean values: $-55.1 \%$ and $-6.65 \%$, respectively) in comparison with those 226 of the groundwater samples (Table 1). The rain water collected during the sampling 
227 campaign had the $\delta^{2} \mathrm{H}$ and $\delta^{18} \mathrm{O}$ values ranging from $-87.2 \%$ to $-10.31 \%$, respectively,

228 which fall within the ranged of groundwater $\delta^{2} \mathrm{H}$ and $\delta^{18} \mathrm{O}$.

\subsection{3 ${ }^{87} \mathrm{Sr}{ }^{86} \mathrm{Sr}$ ratios}

231 Groundwater samples from the Datong basin had a wide range of $\mathrm{Sr}$ concentrations 232 varying from 0.21 to $8.64 \mathrm{mg} / \mathrm{L}$. High concentrations of $\mathrm{Sr}$ are mainly observed in 233 shallow saline groundwater samples collected from wells less than $30 \mathrm{~m}$. The ${ }^{87} \mathrm{Sr} /{ }^{86} \mathrm{Sr}$ 234 values in groundwater changed between 0.70872 and 0.72155 . The groundwater samples 235 from the eastern part of Datong basin had a wider range of $\mathrm{Sr}$ isotope values $236(0.71046 \sim 0.72155)$ than that from the western part $(0.70872 \sim 0.71143)$. And an evident 237 decreasing trend of $\mathrm{Sr}$ isotope signatures was observed in the eastern area from the 238 margin areas to the central part of the basin (Fig. 1), which was related to water-rock 239 interaction along the groundwater flow path. The two surface water samples had ${ }^{87} \mathrm{Sr} /{ }^{86} \mathrm{Sr}$ 240 ratios of 0.71024 and 0.71034 , and $\mathrm{Sr}$ concentrations of 0.88 and $1.02 \mathrm{mg} / \mathrm{L}$, respectively, 241 which were very close to those of groundwater samples from the central area.

\section{$243 \quad 4.2$ Sediment geochemistry and ${ }^{87} \mathrm{Sr} /{ }^{86} \mathrm{Sr}$ signatures}

244 The geochemistry and ${ }^{87} \mathrm{Sr} /{ }^{86} \mathrm{Sr}$ signatures of sediment samples from the Datong 245 basin are presented in Table 2 and Fig. 3. The lithology of sediments from the borehole 246 was light grey to black clay and sand, which were mainly composed of $\mathrm{SiO}_{2}(35.9 \sim 83.8$ 247 wt.\%), $\mathrm{Al}_{2} \mathrm{O}_{3}$ (7.30 15.8 wt.\%) and $\mathrm{CaO}$ (3.31 29.0 wt.\%). High content of organic 248 carbon (OC) was observed in clayey sediment with the maximum of 6.25 wt.\% (Fig. 3c). $249 \mathrm{Sr}$ contents of sediments ranged from 140 to $1150 \mathrm{mg} / \mathrm{kg}$ and had a good correlation with 
250 total organic carbon (TOC) $\left(\mathrm{r}^{2}=0.875\right)($ Fig. $3 \mathrm{~d})$. The ${ }^{87} \mathrm{Sr} /{ }^{86} \mathrm{Sr}$ values of sediments varied 251 from 0.71107 to 0.71612 , which are slightly higher than that of the groundwater sample 252 DT13-04 (0.71047) from the same sampling site and evidently lower than those of 253 bedrock samples (Cambrian shale: 0.74094, Permian sandstone: 0.72358 and Permian 254 siltstone: 0.73558$)$.

255 The iodine contents of sediment ranged from $<0.01$ to $1.81 \mathrm{mg} / \mathrm{kg}$, which is close to 256 that of reported for soils from inland area $(0.89 \sim 1.16 \mathrm{mg} / \mathrm{kg}$ ) (Fordyce et al., 2003), but 257 lower than that of soil samples from coastal areas, such as Norway (up to $15.7 \mathrm{mg} / \mathrm{kg}$, 258 (Frontasyeva and Steinnes, 2004)) and the mean content of worldwide soils 259 (approximately $5.1 \mathrm{mg} / \mathrm{kg}$, Johnson, 2003). The high iodine contents in sediment from the 260 Datong are mainly observed at depths of $\sim 15 \mathrm{~m}$ and $\sim 90 \mathrm{~m}$ (Fig. 3e). The highest iodine 261 content $(1.81 \mathrm{mg} / \mathrm{kg})$ was observed in the grey clayey sediment with depth of $89.1 \mathrm{~m}$, and 262 the groundwater DT13-04 collected from its upper aquifer (67 86 m) had the iodine 263 concentration of $934 \mu \mathrm{g} / \mathrm{L}$, indicating that the iodine-rich sediment serves as the primary 264 source of groundwater iodine. The depth profiles of sediment TOC and iodine show that 265 the sediments with high TOC contents generally had high iodine contents (Fig. 3c, e), 266 suggesting that organic matter could be the important host of iodine in aquifer sediments 267 as documented in our previous studies (Li et al., 2014; Li et al., 2013).

269 5. Discussion

$270 \quad 5.1$ Hydrochemistry of high iodine groundwater

271 Cationic ratios $(\mathrm{Mg} / \mathrm{Na}$ vs. $\mathrm{Ca} / \mathrm{Na}$ molar ratios in Fig. 4) of all groundwater samples 272 were in alignment around the silicate and evaporite end-members, indicating the 
273 dominant controls of aquifer matrix on groundwater chemistry (Gaillardet et al., 1999;

274 Hagedorn and Whittier, 2015). As shown in Fig. 4, the four groundwater samples from

275 the west margin with higher ${ }^{87} \mathrm{Sr} /{ }^{86} \mathrm{Sr}$ ratios are plotted near the silicate end-member, and

276 therefore their hydrochemical and $\mathrm{Sr}$ isotope features are considered to be related to the

277 metamorphic granites and gneiss from the Heng mountains which generally had

278 relatively high ${ }^{87} \mathrm{Sr} /{ }^{86} \mathrm{Sr}$ ratios (Karim and Veizer, 2000; Negrel and Roy, 1998; Negrel et

279 al., 1988; Palmer and Edmond, 1992). Along the groundwater flowpath from the basin

280 margin to central area, the $\mathrm{Mg} / \mathrm{Na}$ and $\mathrm{Ca} / \mathrm{Na}$ molar ratios gradually decrease to those of

281 the evaporite end-member under the effects of hydrolysis of aluminosilicate minerals (Fig.

282 4) (Wang et al., 2009). As a result, the groundwater samples from the discharge area had

283 the ${ }^{87} \mathrm{Sr} /{ }^{86} \mathrm{Sr}$ ratios close to that of sediment samples, and therefore, the evolution of

284 regional groundwater chemistry is mainly controlled by the water-sediment interaction

285 along groundwater flowpath.

286 According to the hydrogeological setting and decreasing trend of groundwater

$287{ }^{87} \mathrm{Sr} /{ }^{86} \mathrm{Sr}$ ratios from the margin area to central area, a groundwater flowpath (\#1 in Fig. 1)

288 was selected for the hydrochemical modeling and the evaluation of water-rock interaction

289 effects on iodine enrichment in groundwater from the central area. Variations of ${ }^{87} \mathrm{Sr} /{ }^{86} \mathrm{Sr}$

290 ratios, TDS, iodine, strontium, DOC and $\mathrm{HCO}_{3}$ concentrations of the five groundwater

291 samples along the model flowpath are shown in Fig. 5. Accordingly, sample DT13-01

292 from the margin area and DT13-04 from the discharge area are selected to represent

293 'initial' and 'final' solutions to conduct inverse geochemical modeling using PHREEQC

294 (Parkhurst and Appelo, 1999), and the result of inverse modeling is shown in Table 3.

295 The TDS range of the five samples was $298.1 \sim 1410 \mathrm{mg} / \mathrm{L}$ (Fig. 5b), which is 
296 significantly lower than that of saline groundwater $(3000 \sim 11330 \mathrm{mg} / \mathrm{L})$ reported in Li et

297 al. (2016), indicating that their hydrochemistry are mainly controlled by the water298 sediment interaction such as cation exchange and mineral dissolution-precipitation rather 299 than the saline processes (Table 3). As shown in Fig. 1, high iodine groundwater mainly 300 occurs in the central part of the Datong basin, and an increasing trend of groundwater 301 iodine from 17.5 to $934 \mu \mathrm{g} / \mathrm{L}$ was observed along the groundwater flowpath (Fig. 5c). 302 Coincidently, the DOC varied in the same way (Fig. 5f). As mentioned above, the 303 sediments with high TOC contents generally had high $\mathrm{Sr}$ and iodine contents, suggesting 304 that the OC-rich clayey sediments might serve as the primary pool for both elements. In 305 the discharge area of the Datong basin, due to water-sediment interaction including the 306 biodegradation of sediment organic matter, soluble $\mathrm{Sr}$ and iodine enriched in radiogenic $307{ }^{87} \mathrm{Sr} /{ }^{86} \mathrm{Sr}$ signature can be introduced into groundwater, thereby causing the observed 308 elevation of Sr isotope ratios in discharge area (Fig. 5a and Fig. 5e). As a result, the 309 degradation of organic matter might introduce $\mathrm{CO}_{2}$ as the final stage of organic carbon 310 into groundwater, which forms $\mathrm{HCO}_{3}$ in solution and leads to the elevation of 311 groundwater $\mathrm{HCO}_{3}$ in the central area. The occurrence of microbially derived $\mathrm{CO}_{2}$ is 312 supported by the results of modeling using PHREEQC which showed a positive mole 313 transfer of $\mathrm{CO}_{2}$ along the groundwater flowpath (Table 3). Meanwhile, because all 314 groundwater samples are oversaturated with respect to calcite and dolomite (Table 1), the 315 precipitation of calcite and/or dolomite would absorb the soluble $\mathrm{Sr}$ due to preferential 316 incorporation of $\mathrm{Sr}$ into carbonate minerals. As the dissolution and adsorption processes 317 proceed, the addition and removal of groundwater $\mathrm{Sr}$ between the groundwater and 318 sediment strongly affect the groundwater Sr concentration and isotope signatures until the 
319 equilibrium is reached. In this study, such an equilibrium assumption is demonstrated by

320 two observations. Firstly, more radiogenic Sr isotopes in groundwater DT13-04 (0.71046)

321 and sediment DXZ-06 (0.71107) from the same sampling site coincidently occur.

322 Secondly, during the equilibrium process, biodegraded organic matter from the sediment

323 should be introduced into groundwater. As a result, groundwater samples with DOC

324 contents higher than $10 \mathrm{mg} / \mathrm{L}$ generally had lower ${ }^{87} \mathrm{Sr} /{ }^{86} \mathrm{Sr}$ compositions

325 (0.71046 0.71095) (Fig. S1). More importantly, during the degradation of iodine-rich

326 organic matter, the iodine sorbed on the clayey sediment would be mobilized into

327 aqueous phases. The difference between groundwater $\mathrm{Sr}$ and iodine is that the iodide,

328 which is the major iodine species in the reducing environment of the Datong basin ( $\mathrm{Li}$ et

329 al., 2014), is difficult to re-incorporated into the precipitated carbonate minerals (Zhang

330 et al., 2013b). Therefore, under the effects of water-sediment interactions, a relatively

331 narrow range of groundwater $\mathrm{Sr}$ concentration was observed (Fig. 5d), while the

332 groundwater iodine concentration exhibited a sharp increase in the discharge area (Fig. $3335 c)$.

334

$335 \quad 5.2$ Vertical mixing process and its influence on iodine enrichment

336 As shown in Table 3, along the groundwater flowpath, cation exchange among Na,

$337 \mathrm{Ca}$ and $\mathrm{Mg}$ causes the addition of $\mathrm{Na}$ and removal of $\mathrm{Ca}$ and $\mathrm{Mg}$, thereby increasing in

$338(\mathrm{Na}+\mathrm{K}) /(\mathrm{Ca}+\mathrm{Mg})$ weight ratio with decrease of groundwater ${ }^{87} \mathrm{Sr} /{ }^{86} \mathrm{Sr}$ ratios (Fig. 6).

339 Meanwhile, several groundwater samples had lower $(\mathrm{Na}+\mathrm{K}) /(\mathrm{Ca}+\mathrm{Mg})$ weight ratios and

$340{ }^{87} \mathrm{Sr} /{ }^{86} \mathrm{Sr}$ signatures, which evidently deviate from the water-rock interaction trend. The

341 two reservoir samples had similar hydrochemical and isotopic characteristics to those 
342 deviating groundwater samples as shown in Fig. 6. The vertical mixing process using the 343 upstream reservoir water as the main irrigation source can introduce surface water into 344 shallow groundwater, which is further supported by groundwater $\delta^{2} \mathrm{H}$ and $\delta^{18} \mathrm{O}$ signatures. 345 The plot of $\delta^{2} \mathrm{H}$ and $\delta^{18} \mathrm{O}$ for all water samples is shown in Fig. 7, where the global 346 meteoric water line (GMWL) (Craig, 1961) and the local meteoric water line (LMWL) 347 (EAEA/WMO, 2007) were also presented. It can be seen that all groundwater samples 348 from the Datong basin fell below the GMWL and below the LMWL. The regression line 349 for the Datong groundwater samples is $\delta^{2} \mathrm{H}=6.018 \delta^{18} \mathrm{O}-16.35 \quad\left(\mathrm{r}^{2}=0.936\right)$. The 350 precipitation sample from Datong basin lies below to the three regression lines, which 351 might be related to evaporation.

352 Two groups with distinctive $\delta^{2} \mathrm{H}$ and $\delta^{18} \mathrm{O}$ features were identified, and Fig. 7a 353 shows that the Group II samples fall along the line between the upstream reservoir water 354 sample and the Group I samples, suggesting the Group II samples are mixtures. During 355 the irrigation, the upstream reservoir water, as the main irrigation source, is delivered into 356 the shallow groundwater ( $\mathrm{Li}$ et al., 2016). The depth profile of water $\delta^{18} \mathrm{O}$ further 357 suggests that the contribution from reservoir water could explain the higher $\delta^{18} \mathrm{O}$ values 358 observed in shallow groundwater (Fig. 7b). The $\delta^{2} \mathrm{H}$ and $\delta^{18} \mathrm{O}$ features can therefore be 359 used to construct a balance model to estimate the contributions from the two end360 members, as applied in previous studies (Halder et al., 2013; Peng et al., 2012; Peng et al., 361 2010a). The equations in terms of $\delta$ values can be expressed as follows:

$$
\delta^{18} O_{I I}=\delta^{18} O_{I} \times R_{I}+\delta^{18} O_{R W} \times R_{R W}
$$

$$
R_{I}+R_{R W}=1
$$


364 where $R_{I}$ and $R_{R W}$ are the weighted contributions from Group I and reservoir water 365 groundwater, respectively. The mean values of $\delta^{18} O$ in the reservoir water and Group I 366 samples were $-6.65 \%\left(\delta^{18} O_{R W}\right)$ and $-11.5 \%\left(\delta^{18} O_{I}\right)$, respectively. By this calculation, 367 the contribution of reservoir water to Group II approximately varies from $29 \%$ to $93 \%$, 368 gradually decreasing with the well depth. The shallow groundwater is heavily influenced 369 by the surface irrigation activities. Notably, the contribution of rainfall was neglected in 370 this two end-members model. As shown in Fig. 7c, the lowest $d$ value of precipitation can 371 act as an end-member leading to the decrease in $d$ values of shallow groundwater, and 372 therefore, the contribution of reservoir water might be overestimated by the two end373 members model.

374 As shown in Fig. 7b, the vertical mixing process mainly influences the shallow 375 groundwater with well depths less than $30 \mathrm{~m}$, and these groundwater samples have iodine 376 concentrations of $17.4 \sim 2180 \mu \mathrm{g} / \mathrm{L}$. From the results of the mixing model, it can be found 377 that the two groundwater samples (DT13-17 and DT13-19), located near the upstream 378 reservoir DT13-28, are dominantly recharged by the upstream reservoir water (Fig. 1 and 379 Fig. 7). The iodine concentrations in these two samples were 143 and $31.1 \mu \mathrm{g} / \mathrm{L}$, 380 respectively, indicating the dilution effect of reservoir water infiltration on groundwater 381 iodine in the shallow aquifer.

382 The DOC concentration of the upstream reservoir is $11.1 \mathrm{mg} / \mathrm{L}$ (Table 1), higher 383 than that of $68 \%$ of the groundwaters, and under the effect of vertical infiltration of 384 upstream water, the additional organic carbon could potentially be introduced into 385 shallow groundwater, causing the elevation of groundwater DOC as shown in Fig. 8a. 386 The downward migration of organic carbon from the surface might provide additional 
energy sources to drive the microbial activity, which has been documented as a major

388 mechanism affecting the iodine behavior (Amachi, 2008; Amachi et al., 2010). In

389 addition, the vertical mixing process also introduces $\mathrm{O}_{2}, \mathrm{NO}_{3}$ and $\mathrm{SO}_{4}$-rich irrigation

390 water into shallow aquifers, leading to the elevation of shallow groundwater Eh values,

$391 \mathrm{NO}_{3}$ and $\mathrm{SO}_{4}$ concentrations (Fig. 8b and Fig. S2). The change of redox potential in

392 shallow groundwater further affects the iodine enrichment and mobilization in shallow

393 aquifers. As reported in our previous studies, (sub)oxidizing condition favors the

394 enrichment of groundwater iodine (Li et al., 2014). The supplement of free oxygen and/or

395 agricultural $\mathrm{NO}_{3}$, ranking at the top of the electron acceptor ladder, provide more energy

396 to the microorganisms, causing the acceleration of degradation of organic matter and the

397 subsequent release of iodine (Arndt et al., 2013; Rivett et al., 2008). Consequently, the

398 co-occurrence of oxidizing condition and high iodine concentrations were observed in the

399 shallow groundwater.

400

4015.3 Conceptual model of iodine enrichment in the groundwater system

402 Based on the spatial distribution of groundwater iodine concentrations and the 403 patterns of isotope signatures, we put forward a conceptual model to illustrate how water404 sediment interaction and vertical infiltration facilitate iodine mobilization (Fig. 9). The 405 phreatic zone is particularly vulnerable to vertical irrigation practices, and therefore its 406 iodine level in groundwater mainly depends on the recharged water. As observed in the 407 Datong basin, the groundwater dominantly affected by irrigation practices has lower 408 iodine concentrations owing to the low level of iodine in upstream reservoir water. In 409 shallow groundwater, the major factor affecting the iodine mobilization is the vertical 
410 transport of organic matter and electron acceptors during irrigation period, which

411 accelerates the microbial oxidation of iodine-bearing clay-organic complexes, releasing

412 iodine into groundwater. The turbulence of irrigation water tends to change the redox

413 potential of the aquifer from sub-reducing to oxidizing, which favors iodine enrichment

414 in groundwater ( $\mathrm{Li}$ et al., 2014). For (medium)deep confined aquifers, the vertical mixing

415 process has limited effect. Similar to shallow groundwater, the organic/iodine-rich clayey

416 sediments act as the primary iodine carrier in the aquifer matrix due to the preferential

417 adsorption of iodine onto organic matter. In these aquifers, the combined influence of

418 intense water-rock interactions and autochthonous microbial activities, as identified from

$419 \mathrm{Sr}$ isotope signatures and $\mathrm{HCO}_{3}$ concentrations, is considered to be the major factor

420 responsible for the elevation of groundwater iodine concentration. Due to the low affinity

421 of iodide onto carbonate minerals, the re-precipitation of carbonate minerals would not

422 cause the retrieval of iodine back onto the sediment, and iodine may persist in

423 groundwater. However, the hydrobiogeochemical mechanism of iodine release from the

424 organic-rich sediment is still an open question, and needs more detailed investigation.

\section{6. Conclusions}

427 At the Datong basin, groundwater iodine concentrations vary from 14.4 to 2180 $428 \mu \mathrm{g} / \mathrm{L}$, while iodine contents in sediments are $<0.01$ to $1.81 \mathrm{mg} / \mathrm{kg}$. High iodine 429 groundwater mainly occurs in the central area of the basin, and can be observed at all 430 well depths. Organic-clayey sediments serve as the primary pool of sediment iodine.

431 Groundwater ${ }^{87} \mathrm{Sr} /{ }^{86} \mathrm{Sr}$ ratios vary from 0.70872 to 0.72155 , and decrease from the basin 432 margin to its central area, in accordance with the regional groundwater flow direction. 
433 The hydrochemical compositions and $\mathrm{Sr}$ isotope features of groundwater and sediment

434 samples suggest the water-sediment interactions, including intense microbial activity,

435 affects the hydrochemistry during flow. Biodegradation of organic matter associated with

436 clayey sediment interlayers and the low affinity of iodide are the primary factors

437 explaining the observed sharp increase of groundwater iodine concentration in the

438 discharge area. The evident stratification of $\delta^{2} \mathrm{H}$ and $\delta^{18} \mathrm{O}$ signatures of surface water and 439 groundwater samples reflects the significance of vertical mixing process. The results of

440 two end-member mixing model show that the groundwater samples most affected by

441 upstream reservoir water contain relatively low iodine concentrations. For high iodine

442 groundwater in shallow aquifers, the input of organic carbon and electron acceptors

443 during irrigation periods is considered to be the main factor favorable for degradation of 444 iodine-bearing clay-organic complexes, thereby leading to iodine release into 445 groundwater.

\section{Acknowledgements}

448 We would like to thank Thomas L. Owens (University of California, Berkeley) and 449 Lanping Feng (State Key Laboratory of Geological Processes and Mineral Resources, 450 China University of Geosciences, Wuhan) for their assistance in Sr isotope analysis in 451 laboratory. The research work was financially supported by National Natural Science 452 Foundation of China (No. 41120124003, No. 41502230 and No. 41521001), the Ministry 453 of Science and Technology of China (2012AA062602), and the Ministry of Education of 454 China (111 project and Priority Development Projects of SRFDP (20120145130001)). 455 The Berkeley laboratory facilities are supported by the U.S. Department of Energy, 
456 Office of Science, Office of Basic Energy Sciences, Chemical Sciences, Geosciences, 457 and Biosciences Division, under Award Number DE-AC02-05CH11231. We thank the 458 anonymous reviewers and the editor for their great help in improving the quality of the 459 manuscript.

460

$461 \quad$ References

462 Amachi, S., 2008. Microbial Contribution to Global Iodine Cycling: Volatilization, Accumulation, 463 Reduction, Oxidation, and Sorption of Iodine. Microbes Environ., 23(4): 269-276.

464 Amachi, S., Kimura, K., Muramatsu, Y., Shinoyama, H., Fujii, T., 2007. Hydrogen peroxide465 dependent uptake of iodine by marine Flavobactefiaceae bacterium strain C-21. Appl.

467 Amachi, S., Minami, K., Miyasaka, I., Fukunaga, S., 2010. Ability of anaerobic microorganisms 468 to associate with iodine: $125 \mathrm{I}$ tracer experiments using laboratory strains and enriched microbial communities from subsurface formation water. Chemosphere, 79(4): 349-354.

470 Amachi, S., Mishima, Y., Shinoyama, H., Muramatsu, Y., Fujii, T., 2005. Active transport and accumulation of iodide by newly isolated marine bacteria. Appl. Environ. Microbiol.,

473 Andersen, S., Petersen, S.B., Laurberg, P., 2002. Iodine in drinking water in Denmark is bound in 474 humic substances. European Journal of Endocrinology, 147(5): 663-670.

475 Arndt, S. et al., 2013. Quantifying the degradation of organic matter in marine sediments: A 476 review and synthesis. Earth Sci. Rev., 123(0): 53-86.

477 Chen, W.J., Li, D.M., Dai, T.M., 1992. The K-Ar age and excess Ar of Quaternary basalt in 478 Datong. The Age and Geochemistry of Cenozoic Volcanic Rocks in China. Seismology $479 \quad$ Press, Beijing. 
Cheng, G.S., 1983. Some thinks on the formation and evolution of Datong downfaulted basin. North China Earthquake Sciences 1(2), 29-36 (in Chinese).

Craig, H., 1961. Isotope variations in meteoric waters. Sci, 133(346): 1702-1703.

Dai, J.L. et al., 2009. Adsorption and desorption of iodine by various Chinese soils: II. Iodide and iodate. Geoderma, 153(1-2): 130-135.

Dansgaard, W., 1964. Stable isotopes in precipitation. Tell, 16(4): 436-468.

Fordyce, F.M., 2003. Database of the iodine content of food and diets populated with data from published literature. British Geological Survey Commissioned Report, CR/03/84N.

Frontasyeva, M.V., Steinnes, E., 2004. Marine gradients of halogens in moss studies by epithermal neutron activation analysis. J. Radioanal. Nucl. Chem., 261(1): 101-106.

Gaillardet, J., Dupré, B., Louvat, P., Allègre, C.J., 1999. Global silicate weathering and CO2 consumption rates deduced from the chemistry of large rivers. Chem. Geol., 159(1-4): 330.

Gu, Y., Hong, H., Xie, X., Wang, Y., 2015. Climate control on the palaeo-lake evolution in the southern Datong Basin, North China: Evidence from 800-ka core records. Quat. Int., 374: 85-92.

Guo, H., Wang, Y., 2004. Hydrogeochemical processes in shallow quaternary aquifers from the northern part of the Datong Basin, China. Appl. Geochem., 19(1): 19-27.

Hagedorn, B., Whittier, R.B., 2015. Solute sources and water mixing in a flashy mountainous stream (Pahsimeroi River, U.S. Rocky Mountains): Implications on chemical weathering rate and groundwater-surface water interaction. Chem. Geol., 391: 123-137.

Halder, J., Decrouy, L., Vennemann, T.W., 2013. Mixing of Rhône River water in Lake Geneva (Switzerland-France) inferred from stable hydrogen and oxygen isotope profiles. J. Hydrol., 477(0): 152-164.

Hansen, V., Roos, P., Aldahan, A., Hou, X., Possnert, G., 2011. Partition of iodine ((129)I and (127)I) isotopes in soils and marine sediments. J. Environ. Radioact., 102(12): 1096-1104. 
Hu, Q.H., Moran, J.E., Gan, J.Y., 2012. Sorption, degradation, and transport of methyl iodide and other iodine species in geologic media. Appl. Geochem., 27(3): 774-781.

IAEA/WMO, 2007. Global Network of Isotopes in Precipitation. The GNIP Database. $<$ http://isohis.iaea.org>.

Johnson, C.C., 2003. Database of the iodine content of soils populated with data from published

Karim, A., Veizer, J., 2000. Weathering processes in the Indus River Basin: implications from literature. British Geological Survey Report CR/03/004N. riverine carbon, sulfur, oxygen, and strontium isotopes. Chem. Geol., 170(1-4): 153-177. from hydrochemistry and fluorescence characteristics. Sci. Total Environ., 468-469(0): $738-745$.

Li, J., Wang, Y., Xie, X., 2016. Cl/Br ratios and chlorine isotope evidences for groundwater salinization and its impact on groundwater arsenic, fluoride and iodine enrichment in the Datong basin, China. Sci. Total Environ., 544: 158-167.

Li, J., Wang, Y., Xie, X., Zhang, L., Guo, W., 2013. Hydrogeochemistry of high iodine groundwater: a case study at the Datong Basin, northern China. Environ. Sci. Proc. Impact, 15(4): 848-859.

Li, H. et al., 2009. Activation of northern margin of the North China Craton in Late Paleozoic: evidence from $\mathrm{U}-\mathrm{Pb}$ dating and $\mathrm{Hf}$ isotopes of detrital zircons from the Upper Carboniferous Taiyuan Formation in the Ningwu-Jingle basin. Chinese Science Bulletin 54, 677-686 (in Chinese).

Negrel, P., Roy, S., 1998. Chemistry of rainwater in the Massif Central (France): a strontium isotope and major element study. Appl. Geochem., 13(8): 941-952.

Negrel, P., Seimbille, F., Allegre, C.J., 1988. Quantitative modelization of differental erosion between crystalline and sedimentary area of a France basin by isotopic analysis of strontium river waters. Chem. Geol., 70(1-2): 13-13. 
Otosaka, S. et al., 2011. Factors controlling mobility of (127)I and (129)I species in an acidic groundwater plume at the Savannah River Site. Sci. Total Environ., 409(19): 3857-3865.

Palmer, M.R., Edmond, J.M., 1992. Controls over the strontium isotope composition of river water. Geochim. Cosmochim. Acta, 56(5): 2099-2111.

Parkhurst, D.L., Appelo, C.A.J., 1999. User's Guide to PHREEQC (ver. 2)-A Computer Geochemical Calculations. U.S. Geological Survey Water-Resources Investigations. U.S. Geological Survey Water-Resources Investigations.

Peng, T.-R. et al., 2012. Using oxygen, hydrogen, and tritium isotopes to assess pond water's contribution to groundwater and local precipitation in the pediment tableland areas of northwestern Taiwan. J. Hydrol., 450-451(0): 105-116.

Peng, T.-R. et al., 2010a. Identification of groundwater sources of a local-scale creep slope: Using environmental stable isotopes as tracers. J. Hydrol., 381(1-2): 151-157.

Peng, T.-R. et al., 2010b. Stable isotopic characteristic of Taiwan's precipitation: A case study of western Pacific monsoon region. Earth Planet. Sci. Lett., 289(3-4): 357-366.

Rivett, M.O., Buss, S.R., Morgan, P., Smith, J.W.N., Bemment, C.D., 2008. Nitrate attenuation in groundwater: A review of biogeochemical controlling processes. Water Res., 42(16): 4215-4232.

Sánchez, V. et al., 2010. Variability in fluid sources in the fluorite deposits from Asturias (N Spain): Further evidences from REE, radiogenic ( $\mathrm{Sr}, \mathrm{Sm}, \mathrm{Nd})$ and stable $(\mathrm{S}, \mathrm{C}, \mathrm{O})$ isotope data. Ore Geol. Rev., 37(2): 87-100.

Schiavo, M.A., Hauser, S., Povinec, P.P., 2009. Stable isotopes of water as a tool to study groundwater-seawater interactions in coastal south-eastern Sicily. J. Hydrol., 364(1-2): 40-49.

Shetaya, W.H., Young, S.D., Watts, M.J., Ander, E.L., Bailey, E.H., 2012. Iodine dynamics in soils. Geochim. Cosmochim. Acta, 77(0): 457-473. 
Shimamoto, Y.S., Itai, T., Takahashi, Y., 2010. Soil column experiments for iodate and iodide using K-edge XANES and HPLC-ICP-MS. J. Geochem. Explor., 107(2): 117-123.

Shimamoto, Y.S., Takahashi, Y., Terada, Y., 2011. Formation of Organic Iodine Supplied as Iodide in a Soil-Water System in Chiba, Japan. Environ. Sci. Technol., 45(6): 2086-2092.

Skrzypek, G., Paul, D., Wojtun, B., 2013. The altitudinal climatic effect on the stable isotope compositions of Agave and Opuntia in arid environments - A case study at the Big Bend National Park, Texas, USA. J. Arid Environ., 92: 102-112.

Smedley, P.L., Nicolli, H.B., Macdonald, D.M.J., Barros, A.J., Tullio, J.O., 2002. Hydrogeochemistry of arsenic and other inorganic constituents in groundwaters from La Pampa, Argentina. Appl. Geochem., 17(3): 259-284.

Stichler, W., Maloszewski, P., Bertleff, B., Watzel, R., 2008. Use of environmental isotopes to define the capture zone of a drinking water supply situated near a dredge lake. J. Hydrol., 362(3-4): 220-233.

Tang, Q. et al., 2013. Geochemistry of iodine-rich groundwater in the Taiyuan Basin of central Shanxi Province, North China. J. Geochem. Explor., 135(0): 117-123.

Wang, X., Løvlie, R., Su, P., Fan, X., 2008. Magnetic signature of environmental change reflected by Pleistocene lacustrine sediments from the Nihewan Basin, North China. Palaeogeogr. Palaeoclimatol. Palaeoecol., 260(3-4): 452-462.

Wang, Y., Shvartsev, S.L., Su, C., 2009. Genesis of arsenic/fluoride-enriched soda water: A case study at Datong, northern China. Appl. Geochem., 24(4): 641-649.

Xie, X. et al., 2011. The sources of geogenic arsenic in aquifers at Datong basin, northern China: Constraints from isotopic and geochemical data. J. Geochem. Explor., 110(2): 155-166.

Xie, X. et al., 2013. Delineation of groundwater flow paths using hydrochemical and strontium isotope composition: A case study in high arsenic aquifer systems of the Datong basin, northern China. J. Hydrol., 476(0): 87-96. 
$583 \mathrm{Xu}, \mathrm{C}$. et al., 2012. Molecular environment of stable iodine and radioiodine (129I) in natural 584 organic matter: Evidence inferred from NMR and binding experiments at 585 environmentally relevant concentrations. Geochim. Cosmochim. Acta, 97(0): 166-182.

$586 \mathrm{Xu}, \mathrm{C}$. et al., 2015. Radioiodine sorption/desorption and speciation transformation by subsurface 587 sediments from the Hanford Site. J. Environ. Radioact., 139: 43-55.

588 Zhang, E. et al., 2013a. Iodine in groundwater of the North China Plain: Spatial patterns and 589 hydrogeochemical processes of enrichment. J. Geochem. Explor., 135(0): 40-53.

590 Zhang, S. et al., 2013b. Iodine-129 and Iodine-127 Speciation in Groundwater at the Hanford Site, 591 U.S.: Iodate Incorporation into Calcite. Environ. Sci. Technol., 47(17): 9635-9642.

592 Zhou, T.R. et al., 1991. Cenozoic Palaeogeography of the Nihewan Basin. Science Press, Beijing $593 \quad$ (in Chinese).

594 


\section{$595 \quad$ Figure Caption}

596 Fig. 1 Topographic and simplified geological map and sampling location of water

597 samples at the Datong basin.

598 Fig. 2 The depth profile of groundwater iodine in the Datong basin.

599 Fig. 3 Depth profiles of $\mathrm{SiO}_{2}(\mathrm{a}), \mathrm{CaO}$ (b), TOC (c), $\mathrm{Sr}$ (d) and iodine (e) contents of the 600 borehole DXZ from the iodine-affected area in the Datong basin shown in Fig. 1.

601 Fig. 4 Plot of $\mathrm{Mg} / \mathrm{Na}$ vs. $\mathrm{Ca} / \mathrm{Na}$ molar ratios in the water samples from the Datong basin.

602 Fig. 5 Variations of ${ }^{87} \mathrm{Sr} /{ }^{86} \mathrm{Sr}$ ratios (a), TDS (b), iodine (c), strontium (d), $\mathrm{HCO}_{3}$ (e) and 603 DOC (f) concentrations along the groundwater flowpath from the basin margin to the 604 central area (\#1 in Fig. 1).

605 Fig. 6 The plots of $(\mathrm{Na}+\mathrm{K}) /(\mathrm{Ca}+\mathrm{Mg})$ vs. ${ }^{87} \mathrm{Sr} /{ }^{86} \mathrm{Sr}$ for water samples from the Datong 606 basin.

607 Fig. 7 The plot of $\delta^{18} \mathrm{O}$ and $\delta^{2} \mathrm{H}$ of water samples from the Datong basin with the Global 608 Meteoric Water Line (GMWL; data from (Craig, 1961)) and Local Meteoric Water Line 609 (LMWL; data from EAEA/WMO, 2007), and the depth profiles of Group II $\delta^{18} \mathrm{O}$ (b) and $610 d$-excess (c) of groundwater from the Datong basin. The $d$-excess of water is defined as $d$ $611=\delta^{2} \mathrm{H}-8 \times \delta^{18} \mathrm{O}($ Dansgaard, 1964)

612 Fig. 8 The potential effects of vertical mixing process on iodine mobilization in the 613 shallow groundwater. The depth profile of sediment iodine refers to the DXZ borehole 614 shown in Fig. 1.

615 Fig. 9 The conceptual model for major processes and factors controlling iodine 616 mobilization in shallow groundwater systems. 


\section{Table Caption}

619 Table 1 Chemical and isotopic compositions of groundwater samples from the Datong

620 basin.

621 Table 2 Chemical and isotopic compositions of sediment ssamples from the Datong basin.

622 Table 3 Results of mass transfer calculation using PHREEQC.

623

624

625

626

627

628

629 


\section{Figure Captions}

Fig. 1 Topographic and simplified geological map and sampling location of water samples at the Datong basin.

Fig. 2 The depth profile of groundwater iodine in the Datong basin.

Fig. 3 Depth profiles of $\mathrm{SiO}_{2}(\mathrm{a}), \mathrm{CaO}$ (b), $\mathrm{TOC}(\mathrm{c}), \mathrm{Sr}$ (d) and iodine (e) contents of the borehole DXZ from the iodine-affected area in the Datong basin shown in Fig. 1.

Fig. 4 Plot of $\mathrm{Mg} / \mathrm{Na}$ vs. $\mathrm{Ca} / \mathrm{Na}$ molar ratios in the water samples from the Datong basin.

Fig. 5 Variations of ${ }^{87} \mathrm{Sr} /{ }^{86} \mathrm{Sr}$ ratios (a), TDS (b), iodine (c), strontium (d), $\mathrm{HCO}_{3}$ (e) and DOC (f) concentrations along the groundwater flowpath from the basin margin to the central area (\#1 in Fig. 1).

Fig. 6 The plots of $(\mathrm{Na}+\mathrm{K}) /(\mathrm{Ca}+\mathrm{Mg})$ vs. ${ }^{87} \mathrm{Sr} /{ }^{86} \mathrm{Sr}$ for water samples from the Datong basin.

Fig. 7 The plot of $\delta^{18} \mathrm{O}$ and $\delta^{2} \mathrm{H}$ of water samples from the Datong basin with the Global Meteoric Water Line (GMWL; data from (Craig, 1961)) and Local Meteoric Water Line (LMWL; data from EAEA/WMO, 2007), and the depth profiles of Group II $\delta^{18} \mathrm{O}$ (b) and $d$-excess (c) of groundwater from the Datong basin. The $d$-excess of water is defined as $d$ $=\delta^{2} \mathrm{H}-8 \times \delta^{18} \mathrm{O}($ Dansgaard, 1964).

Fig. 8 The potential effects of vertical mixing process on iodine mobilization in the shallow groundwater. The depth profile of sediment iodine refers to the DXZ borehole shown in Fig. 1.

Fig. 9 The conceptual model for major processes and factors controlling iodine mobilization in shallow groundwater systems. 


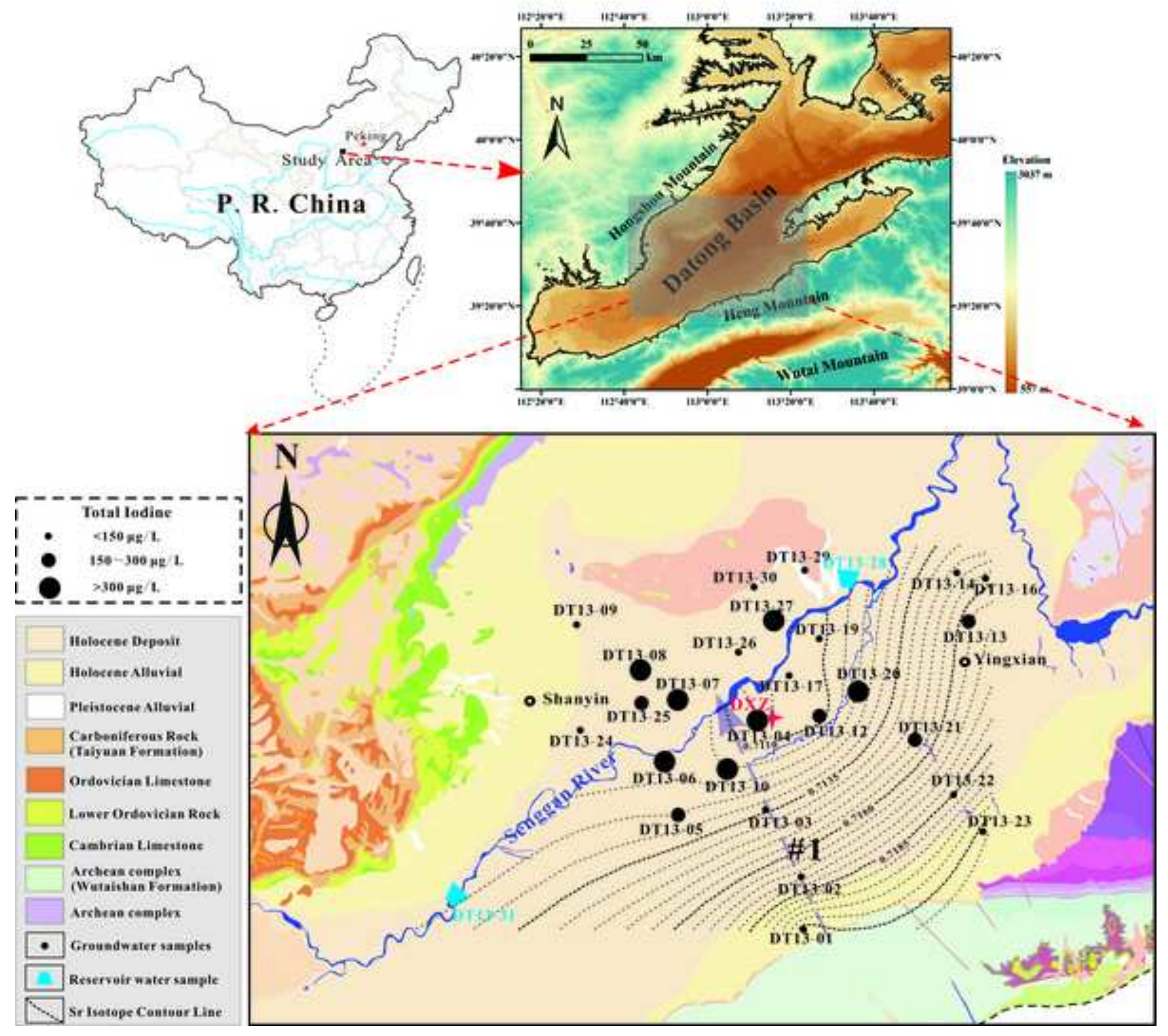




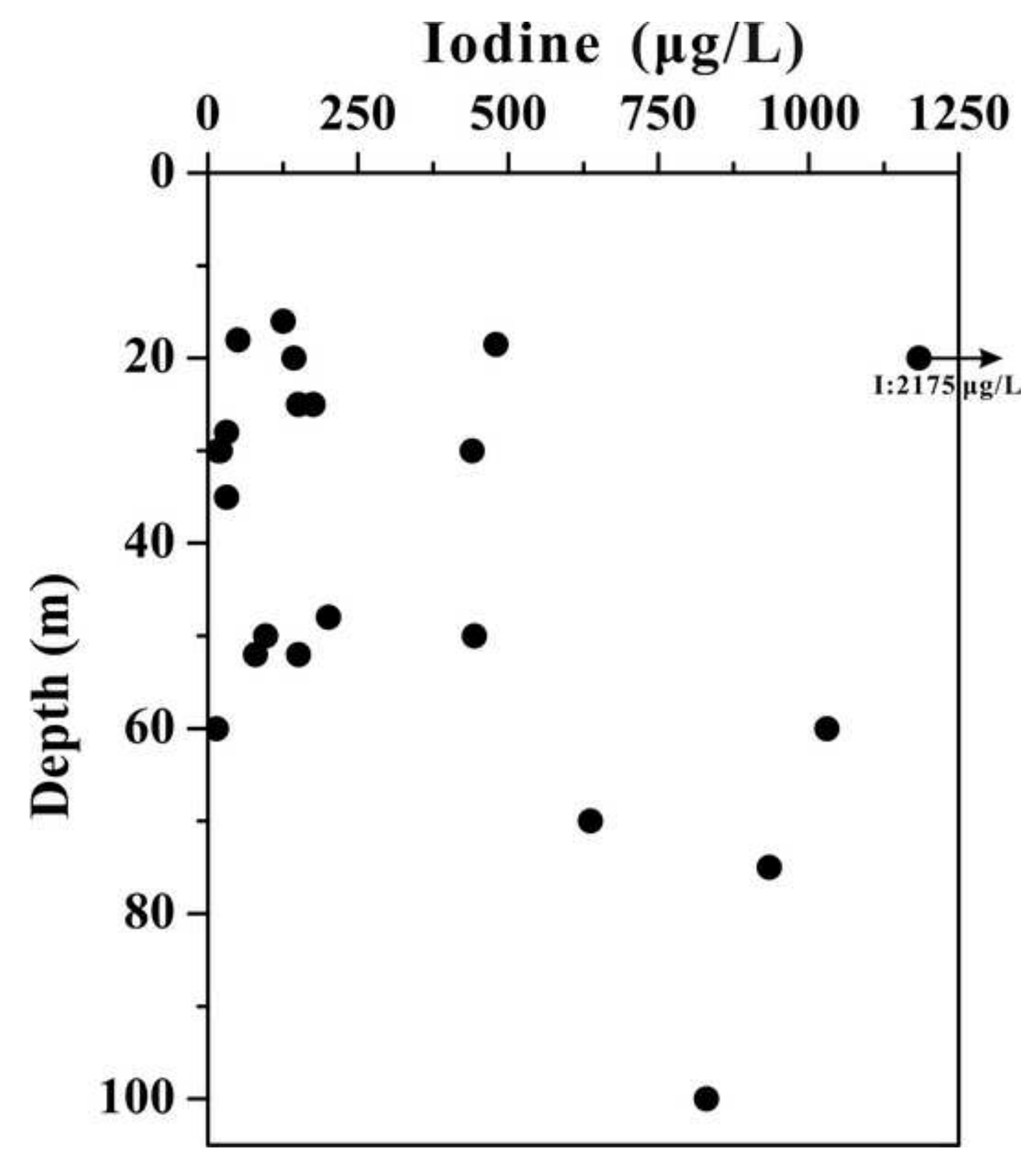

Figure

Pho
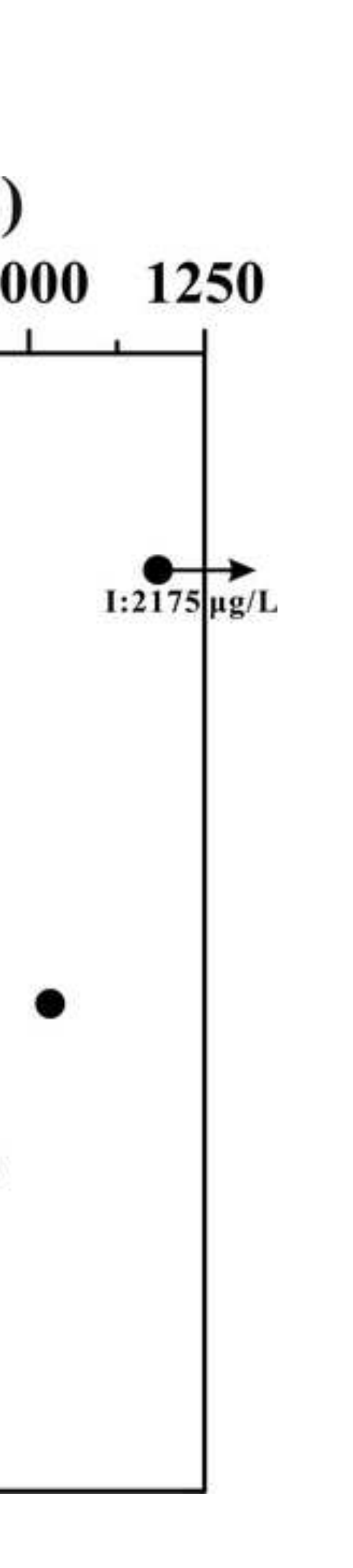

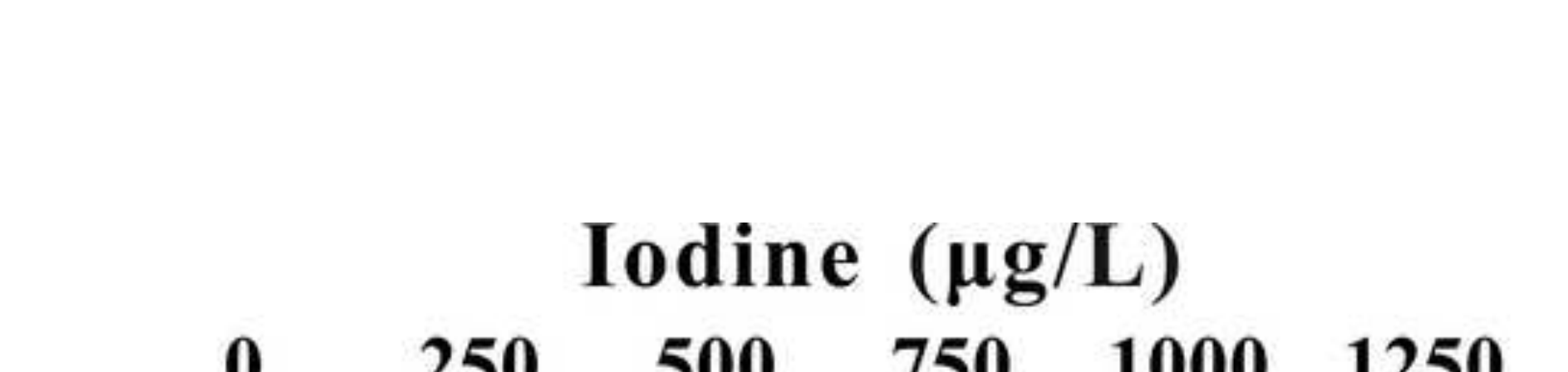

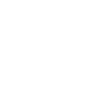




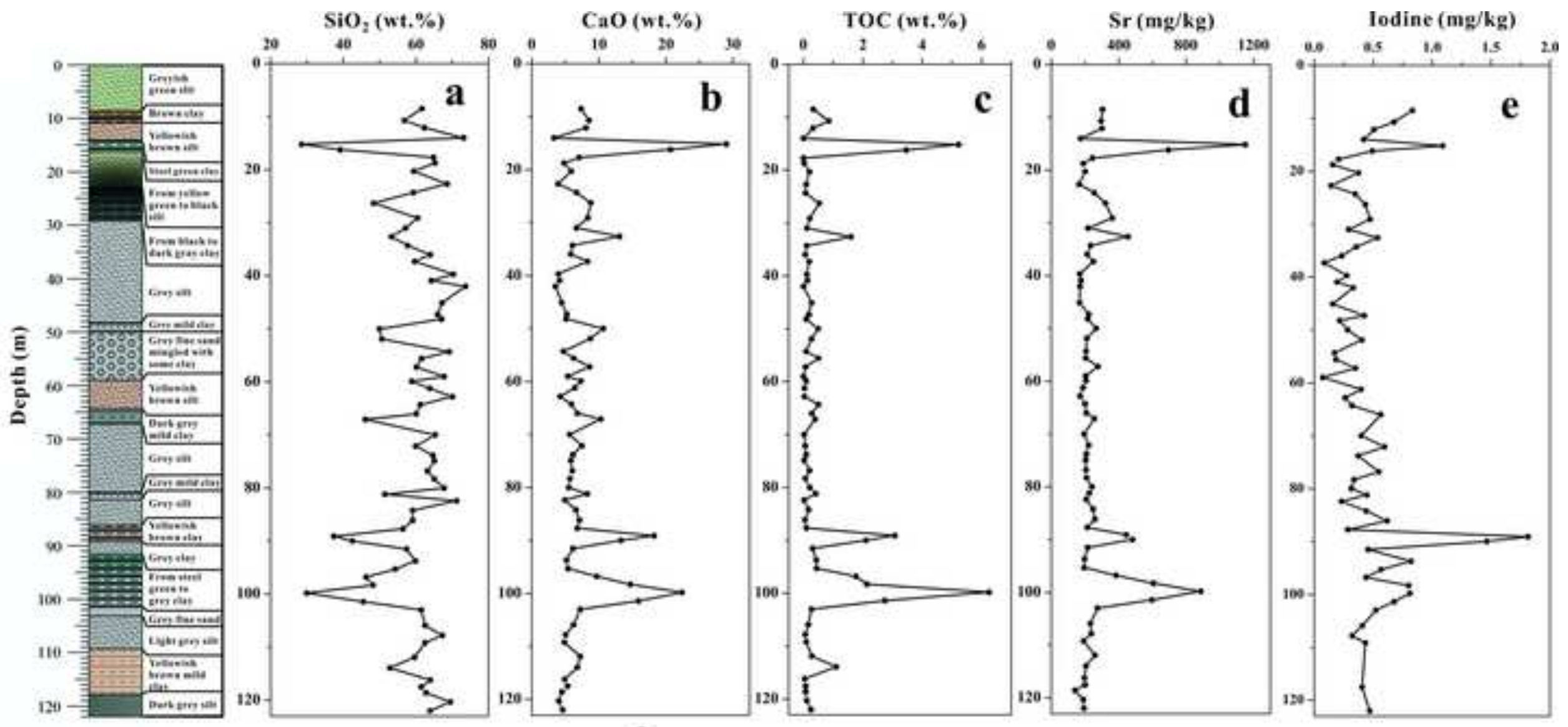




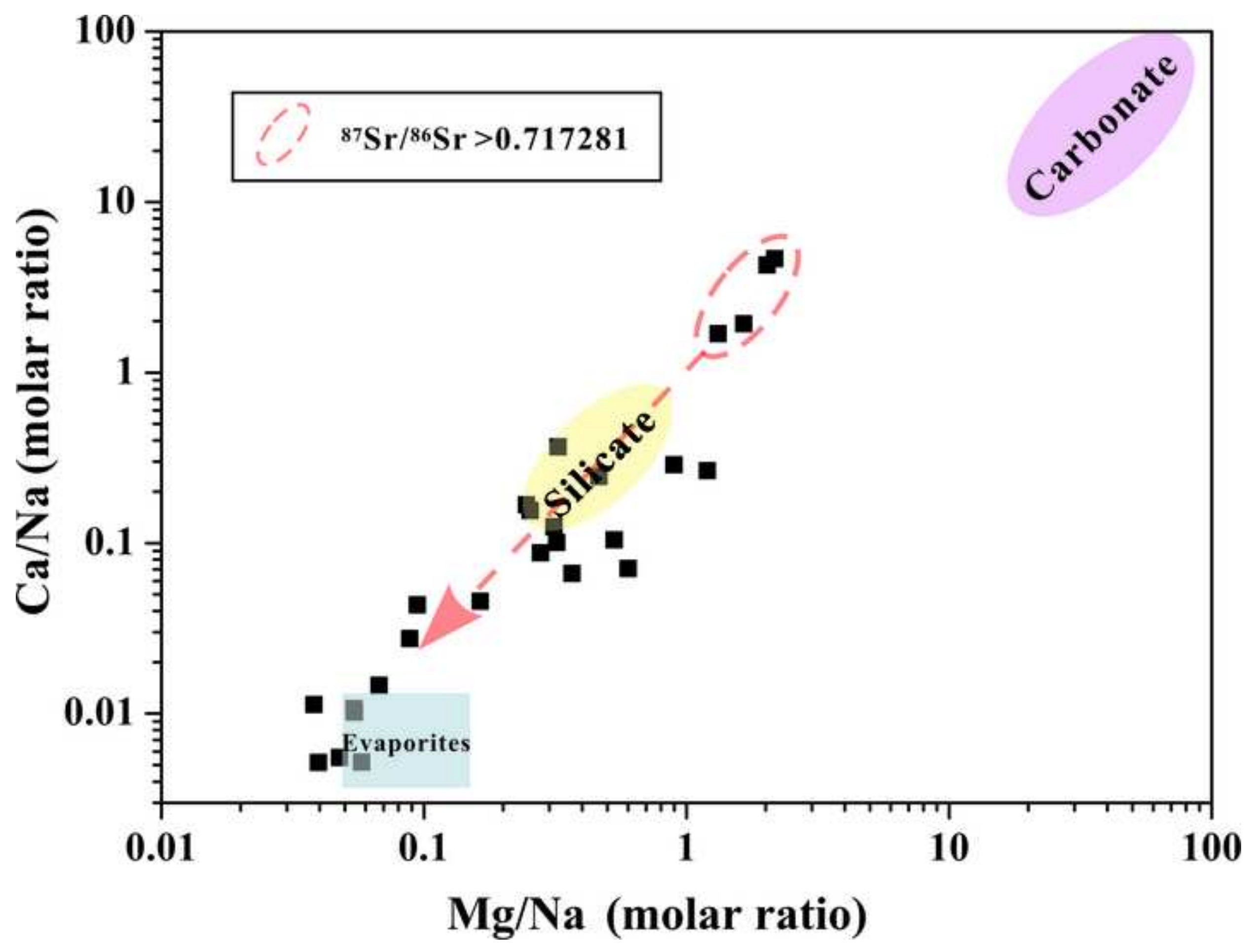



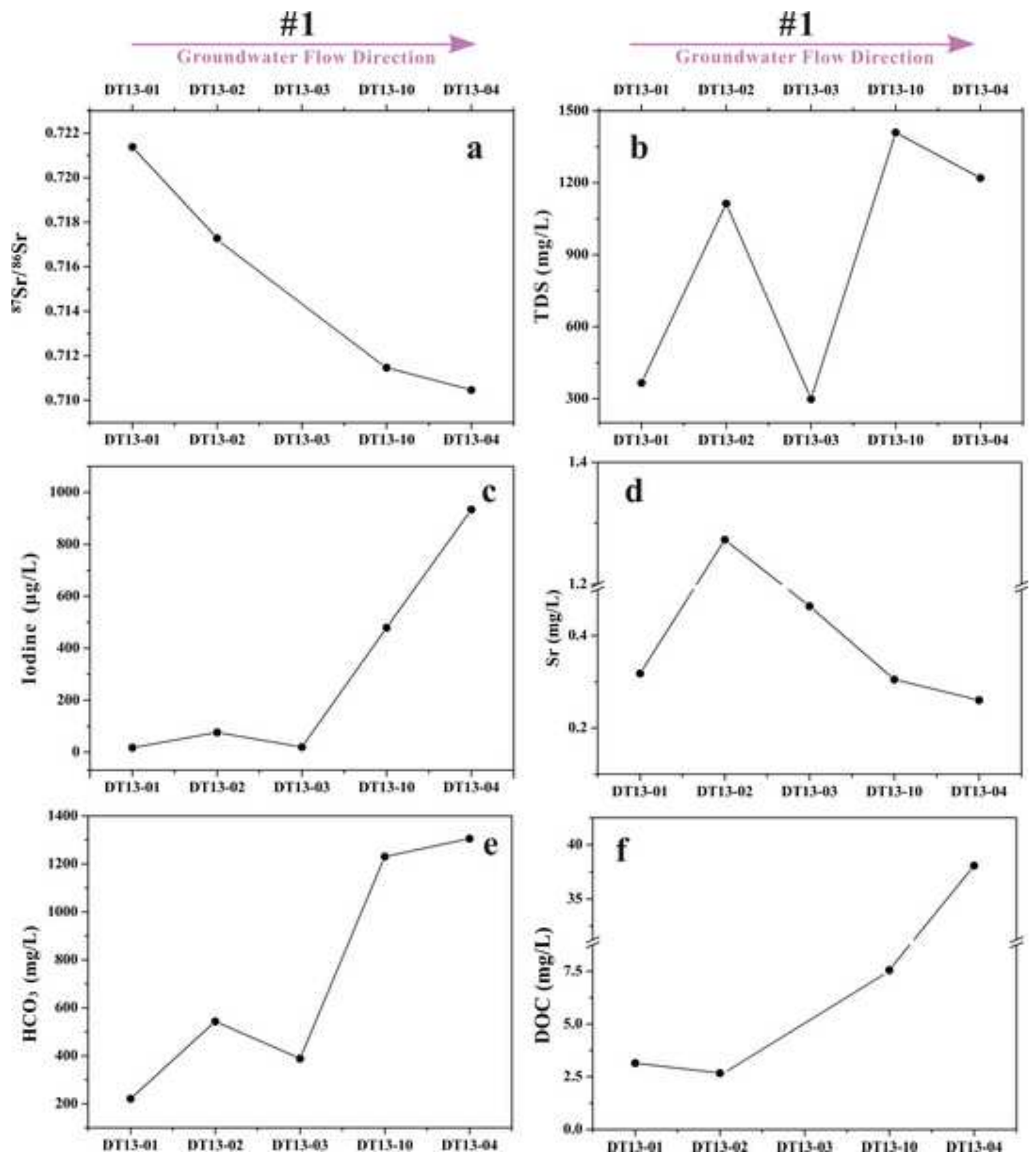


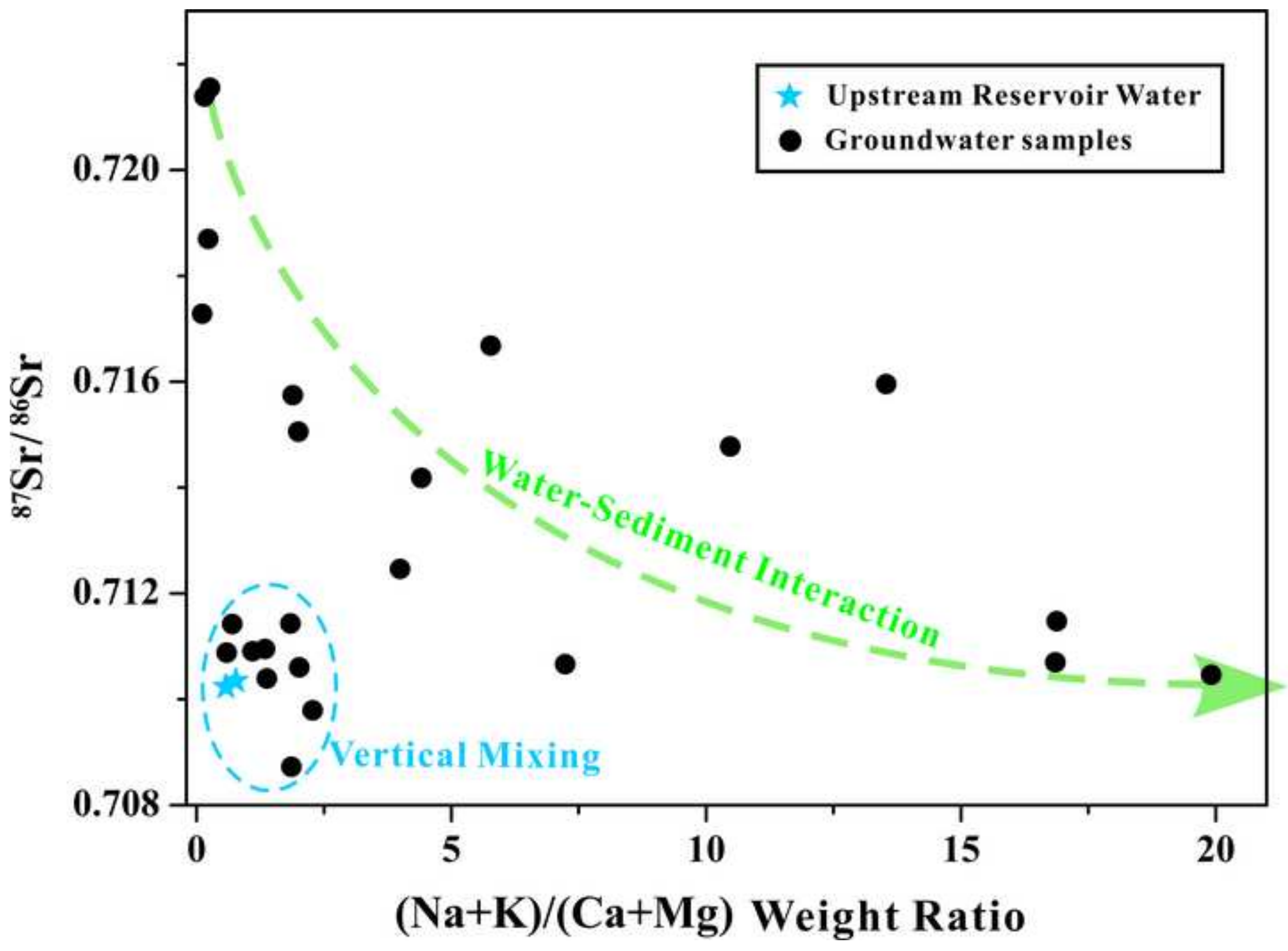



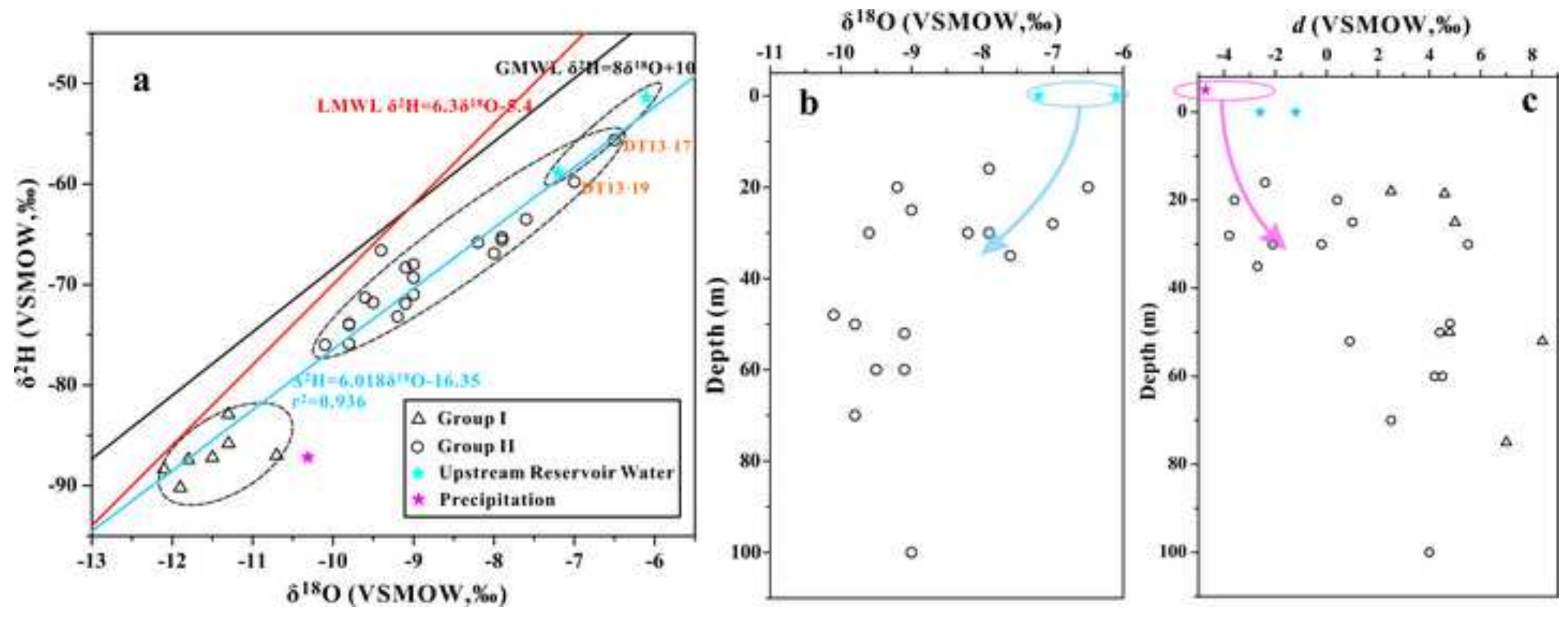


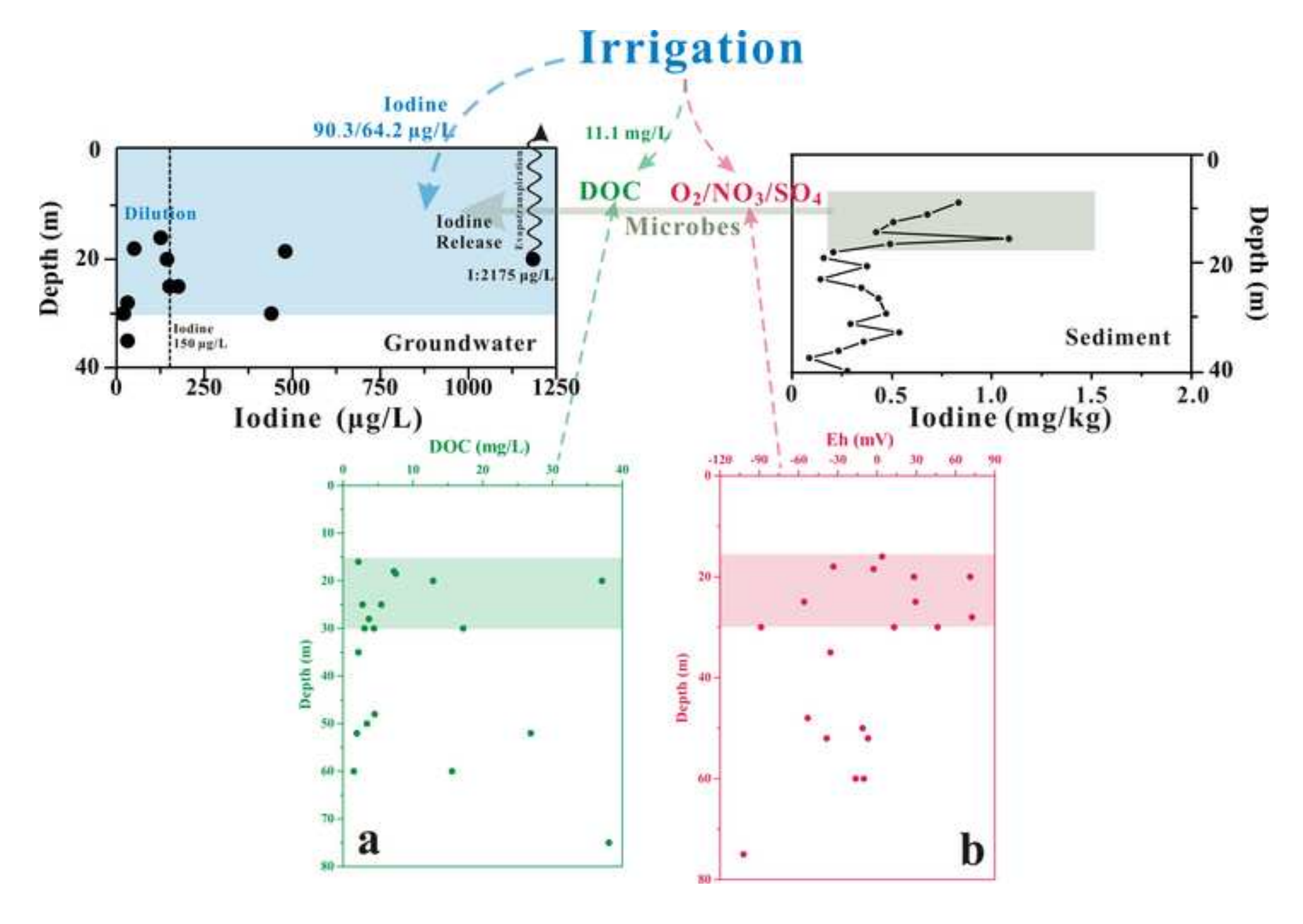

8




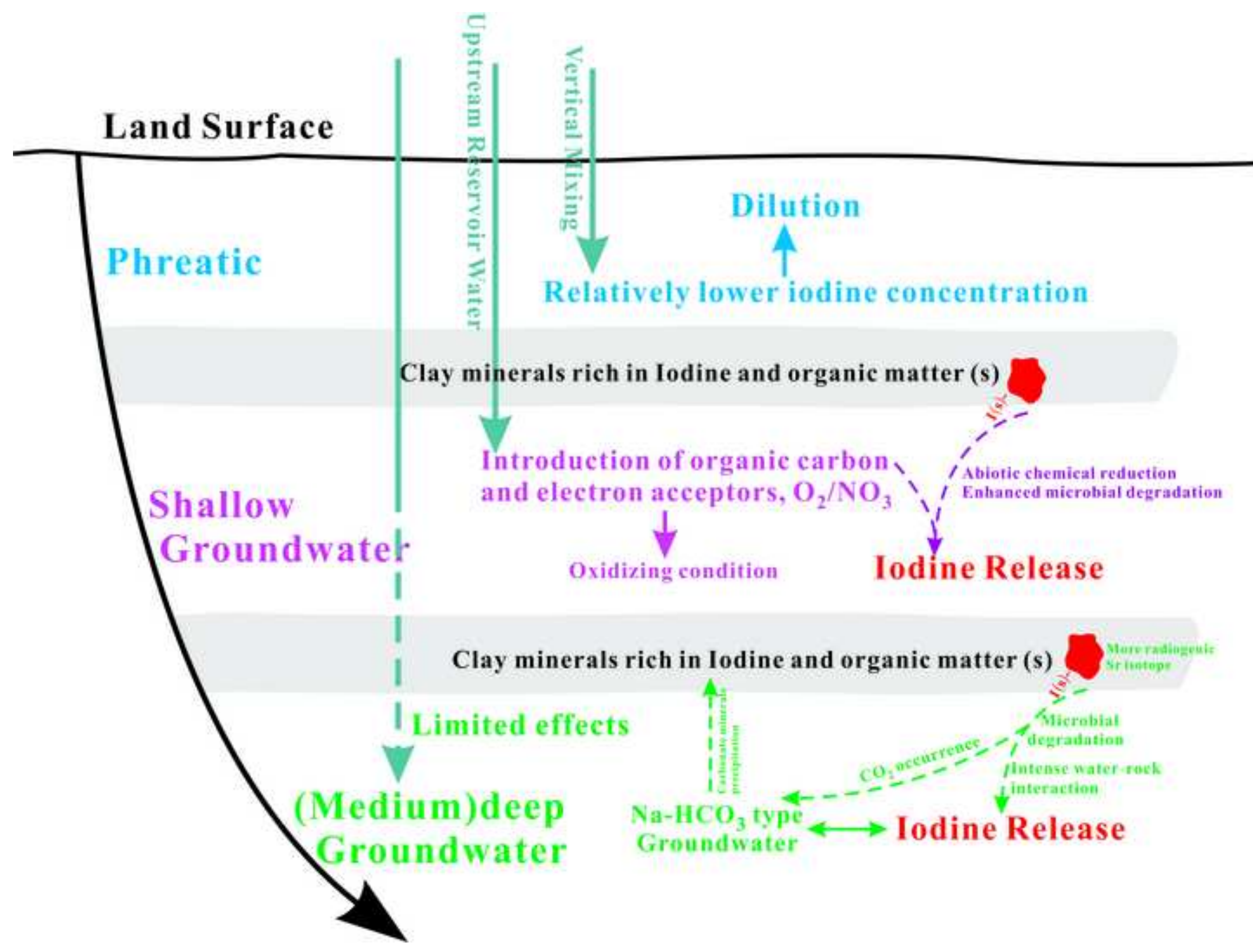
I. Enhanced microbial degradation

Shatlow

Oxidizing condition

Iodine Release

(1)

Land Surface

Phreatic

(Medium)deep

Groundwater Groundwater (1) Limited effects

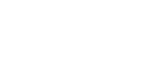

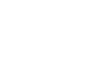

Relatively lower iodine concentration

Clay minerals rich in Iodine and organic matter (s) 
Table 1 Chemical and isotopic compositions of groundwater samples from the Datong basin.

\begin{tabular}{|c|c|c|c|c|c|c|c|c|c|c|c|c|c|c|c|c|c|c|c|c|c|c|c|c|c|}
\hline \multirow{2}{*}{ ID } & \multirow{2}{*}{ water type } & \multirow{2}{*}{$\begin{array}{c}\text { Depth } \\
\mathrm{m}\end{array}$} & \multirow{2}{*}{$\mathrm{pH}$} & \multirow{2}{*}{$\begin{array}{l}\mathrm{Eh} \\
\mathrm{mV}\end{array}$} & \multirow{2}{*}{$\begin{array}{l}\mathrm{TDS} \\
\mathrm{mg} / \mathrm{L}\end{array}$} & \multirow{2}{*}{${ }^{87} \mathrm{Sr} /{ }^{86} \mathrm{Sr}$} & \multirow{2}{*}{$\sigma$} & \multirow{2}{*}{$\begin{array}{c}\delta^{2} \mathrm{H} \\
\text { \%o V-SMOW }\end{array}$} & \multirow{2}{*}{$\begin{array}{c}\delta^{18} \mathrm{O} \\
\% \text { \%-SMOW \% }\end{array}$} & \multirow{2}{*}{$\begin{array}{c}d^{c} \\
\text { \%o V-SMOW }\end{array}$} & \multicolumn{4}{|c|}{ DOC Iodine Calcite Dolomite } & \multirow{2}{*}{$\begin{array}{c}\mathrm{F} \\
\mathrm{mg} / \mathrm{L}\end{array}$} & \multirow{2}{*}{$\begin{array}{c}\mathrm{Cl} \\
\mathrm{mg} / \mathrm{L}\end{array}$} & \multirow{2}{*}{$\begin{array}{r}\mathrm{NO}_{3} \\
\mathrm{mg} / \mathrm{L} \\
\end{array}$} & \multirow{2}{*}{\multicolumn{2}{|c|}{$\begin{array}{c}\mathrm{SO}_{4} \mathrm{HCO}_{3} \\
\mathrm{mg} / \mathrm{L} \mathrm{mg} / \mathrm{L}\end{array}$}} & \multirow{2}{*}{$\begin{array}{c}\mathrm{K} \\
\mathrm{mg} / \mathrm{L}\end{array}$} & \multirow{2}{*}{$\begin{array}{c}\mathrm{Na} \\
\mathrm{mg} / \mathrm{L}\end{array}$} & \multirow{2}{*}{$\begin{array}{c}\mathrm{Ca} \\
\mathrm{mg} / \mathrm{L}\end{array}$} & \multirow{2}{*}{$\begin{array}{c}\mathrm{Mg} \\
\mathrm{mg} / \mathrm{Lr}_{1}\end{array}$} & \multirow{2}{*}{$\begin{array}{c}\mathrm{Si} \\
\mathrm{mg} / \mathrm{L}_{1}\end{array}$} & $\mathrm{Sr}$ \\
\hline & & & & & & & & & & & $\mathrm{N} \mathrm{mg/L}$ & $\mu \mathrm{g} / \mathrm{L}$ & $\mathrm{SI}^{\mathrm{a}}$ & SI & & & & & & & & & & & $\mathrm{mg} / \mathrm{L}$ \\
\hline T13-01 & $\mathrm{Ca}-\mathrm{HCO}_{3}$ & $--^{\mathrm{e}}$ & 8.59 & 37.7 & 365.4 & 0.72138 & 0.00057 & -66.6 & -9.4 & 8.6 & 3.15 & 17.5 & 1.191 & 2.190 & $<0.01$ & 11.5 & 31.4 & 111 & 221 & 4.39 & 9.18 & 68.2 & 19.4 & 5.74 & 0.32 \\
\hline DT13-02 & $\mathrm{Ca}-\mathrm{HCO}_{3}$ & -- & 7.3 & -35 & 1113 & 0.71728 & 0.00083 & -73.9 & -9.8 & 4.5 & 2.67 & 75.9 & 0.6499 & 1.091 & $<0.01$ & 123 & $<0.01$ & 1404 & 543 & 3.31 & 27.3 & 221 & 61.6 & 8.21 & 1.27 \\
\hline DT13-03 & $\mathrm{Na}-\mathrm{HCO}_{3}$ & -- & 8.07 & -- & 298.1 & -- & -- & -82.9 & -11.3 & 7.5 & -- & 19.1 & 0.6709 & 1.424 & 0.21 & 14.6 & $<0.01$ & 13.18 & 388 & 0.87 & 43.2 & 27.5 & 14.6 & 6.27 & 0.47 \\
\hline DT13-04 & $\mathrm{Na}-\mathrm{HCO}_{3}$ & 75 & 8.3 & -102 & 1220 & 0.71046 & 0.00089 & -87.4 & -11.8 & 7.0 & 38.1 & 34 & 0.1964 & 428 & 1.01 & 171 & $<0.01$ & 112 & 1310 & 0.30 & 366 & 3.30 & 15.1 & 4.39 & 0.26 \\
\hline DT13-05 & $\mathrm{Na}-\mathrm{HCO}_{3}$ & 25 & 7.96 & -56 & 856.4 & 0.71246 & 0.00054 & -90.2 & -11.9 & 5.0 & 5.48 & 175 & 0.4225 & 1.535 & 0.37 & 208 & $<0.01$ & 150.1 & 635 & $<0.01$ & 225 & 17.8 & 38.4 & 6.03 & 0.53 \\
\hline DT13-06 & $\mathrm{Na}-\mathrm{HCO}_{3}$ & 50 & 8.47 & -- & 1001 & -- & -- & -87.2 & -11.5 & 4.8 & -- & 444 & 0.2 & 35 & 0.46 & 185 & $<0.01$ & 6 & 903 & 1.13 & 324 & 2.94 & 19.5 & 4.94 & 0.25 \\
\hline ОТ13-07 & $\mathrm{Na}-\mathrm{Cl}$ & 100 & 9.28 & -- & 2191 & -- & -- & -68 & -9 & 4.0 & -- & 830 & -0.0412 & 0.767 & $<0.01$ & 917 & $<0.01$ & 1357 & 352 & 73.1 & 623 & 11.0 & 35.2 & 21.1 & 0.34 \\
\hline DT13-08 & $\mathrm{Mg}-\mathrm{Cl}$ & 60 & 7.44 & -16 & 7187 & 0.71095 & 0.00055 & -68.3 & -9.1 & 4.5 & 15.6 & 1030 & 0.5126 & 2.087 & $<0.01$ & 2400 & 897 & 1680 & 879 & 2.90 & 1010 & 125 & 634 & 6.14 & 8.64 \\
\hline DT13-09 & $\mathrm{Na}-\mathrm{HCO}_{3}$ & 52 & 7.97 & -6.9 & 420.5 & 0.71143 & 0.00323 & -71.9 & -9.1 & 0.9 & 1.96 & 79 & 0.3541 & 1.005 & 1.20 & 27.6 & 34.8 & 62.3 & 334 & 0.85 & 82.6 & 24.1 & 21.2 & 6.62 & 0.80 \\
\hline DT1 & $\mathrm{Na}-\mathrm{HCO}_{3}$ & 19 & 8.28 & -2.7 & 1410 & 0.71147 & 0.00060 & -85.8 & -11.3 & 4.6 & .56 & 479 & 0.5176 & 1.706 & 2.61 & 173 & $<0.01$ & 1179 & 1230 & 1.02 & 418 & 8.23 & 16.6 & 5.51 & 0.30 \\
\hline DT13-12 & $\mathrm{Na}-\mathrm{HCO}_{3}$ & 52 & 8.53 & -39 & 980.8 & 0.71070 & 0.00056 & -88.4 & -12.1 & 8.4 & 26.9 & 51 & 0.2801 & 1.656 & 1.11 & 113 & $<0.01$ & 113.2 & 1080 & 0.37 & 297 & 2.85 & 14.8 & 4.41 & 0.21 \\
\hline DT13-13 & $\mathrm{Na}-\mathrm{HCO}_{3}$ & 48 & 7.88 & -53 & 1413 & 0.71668 & 0.00057 & -76 & -10.1 & 4.8 & 4.52 & 201 & 0.6771 & 1.825 & 0.65 & 178 & 11.9 & 246 & 1014 & 1.39 & 399 & 30.1 & 39.3 & 5.07 & 0.61 \\
\hline DT13-14 & $\mathrm{Na}-\mathrm{HCO}_{3}$ & 50 & 7.76 & -11 & 965.1 & 0.71575 & 0.00093 & -74 & -9.8 & 4.4 & 3.43 & 96.1 & 0.642 & 1.627 & 0.69 & 104 & 7.26 & 191 & 756 & 2.33 & 184 & 49.7 & 48.7 & 5.71 & 0.92 \\
\hline DT13-16 & $\mathrm{Na}-\mathrm{HCO}_{3}$ & 18 & 8.13 & -33 & 1950 & 0.71477 & 0.00057 & -69.5 & -9 & 2.5 & 7.29 & 50.1 & 0.5637 & 1.924 & 4.17 & 313 & 27.4 & 448 & 1090 & 1.45 & 560 & 14.3 & 39.3 & 5.00 & 0.61 \\
\hline DT13-17 & $\mathrm{Na}-\mathrm{SO}_{4}$ & 20 & 7.28 & 28.1 & 8324 & 0.71091 & 0.00121 & -55.6 & -6.5 & -3.6 & 12.9 & 143 & 0.6563 & 1.706 & $<0.01$ & 1140 & 655 & 4210 & 571 & 3.77 & 1060 & 454 & 515 & 5.58 & 7.63 \\
\hline DT1 & $\mathrm{Mg}-\mathrm{HCO} 3$ & 28 & 7.7 & 72 & 1172 & 0.7 & 00118 & -59.8 & -7 & -3 & 7 & .1 & & & 0 & 195 & 319 & 114 & 514 & 1.06 & 105 & 48.9 & 132 & 5.93 & 3.70 \\
\hline DT13-20 & $\mathrm{Na}-\mathrm{Cl}$ & 20 & 8.07 & 71 & 6275 & 0.7 & 0.00079 & -73.2 & -9.2 & & 1 & & & 23 & $<$ & 1780 & 87.6 & 1410 & 2120 & 27.5 & 1780 & 33.2 & 100 & 5.28 & 1.18 \\
\hline DT 1 & $\mathrm{Na}-\mathrm{HCO}_{3}$ & 25 & 8.0 & 29 & 80 & 0.7 & 0.00058 & -71 & -9 & 1.0 & 9 & 1 & 0.6268 & 1.891 & 0.92 & 105 & 55.2 & 86.4 & 42 & 2.34 & 154 & 26.9 & 51.4 & 4.38 & 0.81 \\
\hline DT13-22 & $\mathrm{Ca}-\mathrm{HCO}_{3}$ & 30 & 7.81 & 12.9 & 659.9 & 0.71870 & 0.00108 & -71.3 & -9.6 & 5.5 & 3.09 & 21.1 & 0.4608 & 1.023 & $<0.01$ & 171 & $<0.01$ & 1138 & 316 & 3.98 & 31.1 & 104 & 53.5 & 7.39 & 0.99 \\
\hline DT13-23 & $\mathrm{Ca}-\mathrm{HCO}_{3}$ & 60 & 7.75 & -10 & 405.2 & 0.72155 & 0.0007 & -71.8 & -9.5 & 4.2 & 1.53 & 14.4 & 0.5529 & 1.127 & 0.26 & 18.1 & 7.00 & 44.3 & 456 & 2.56 & 19.7 & 58.2 & 27.1 & 7.21 & 0.56 \\
\hline DT13-24 & $\mathrm{Mg}-\mathrm{HCO}_{3}$ & 30 & 7.26 & 46.3 & 1906 & 0.71142 & 0.00041 & -65.8 & -8.2 & -0.2 & 4.43 & 17.4 & 0.3211 & 1.263 & $<0.01$ & 359 & 373 & 384 & 655 & 0.15 & 190 & 95.4 & 177 & 6.13 & 4.87 \\
\hline DT13-25 & $\mathrm{Na}-\mathrm{SO}_{4}$ & -- & 8.93 & 16.5 & 2120 & 0.71067 & 0.00078 & -87 & -10.7 & -1.4 & 2.02 & 158 & 0.9540 & 2.543 & $<0.01$ & 566 & $<0.01$ & 1784 & 299 & 5.70 & 539 & 25.8 & 49.6 & 5.78 & 1.52 \\
\hline DT13-26 & $\mathrm{Na}-\mathrm{HCO}_{3}$ & 16 & 8.1 & 3.8 & 749.8 & 0.70979 & 0.00080 & -65.6 & -7.9 & -2.4 & 2.2 & 125 & 0.448 & 1.526 & 1.58 & 115 & 76.2 & 148 & 383 & 1.34 & 151 & 23.1 & 43.7 & 5.64 & 0.68 \\
\hline DT13-27 & $\mathrm{Na}-\mathrm{Cl}$ & 30 & 7.63 & -89 & 10150 & 0.71060 & 0.00057 & -65.3 & -7.9 & -2.1 & 17.2 & 439 & 0.8737 & 2.611 & $<0.01$ & 3300 & $<0.01$ & 13520 & 755 & 6.03 & 1970 & 228 & 751 & 7.73 & 6.81 \\
\hline DT13-29 & $\mathrm{Mg}-\mathrm{HCO}_{3}$ & -- & 8.29 & -- & 472.7 & 0.71039 & 0.00078 & -66.9 & -8 & -2.9 & 2.71 & 18.8 & 0.4203 & 1.678 & 2.60 & 24.1 & 11.9 & 102 & 409 & 1.09 & 74.4 & 13.6 & 41.2 & 5.21 & 0.87 \\
\hline DT13-30 & $\mathrm{Na}-\mathrm{NO}_{3}$ & 35 & 7.91 & -36 & 943.7 & 0.70872 & 0.00094 & -63.5 & -7.6 & -2.7 & 2.19 & 30.9 & 0.3090 & 1.148 & $<0.01$ & 144 & 360 & 47.7 & 302 & 1.97 & 155 & 33.7 & 50.5 & 8.35 & 1.05 \\
\hline DT13-31 & -- & -- & 8.63 & -- & 431.2 & 0.71024 & 0.00071 & -58.8 & -7.2 & -1.2 & 11.1 & 64.2 & -- & -- & 0.71 & 49.6 & 8.95 & 173 & 160 & 5.05 & 38.8 & 52.3 & 23.2 & 3.80 & 0.88 \\
\hline DT13-28 & -- & -- & -- & -- & 508.2 & 0.71034 & 0.00062 & -51.4 & -6.1 & -2.6 & -- & 90.3 & 0.9645 & 1.926 & 0.60 & 71.5 & $<0.01$ & 1198 & 183 & 6.63 & 57.5 & 53.1 & 30.3 & 0.93 & 1.02 \\
\hline
\end{tabular}

\section{SI: Saturation index;}

WR: Weight ratio;

$d=\delta^{2} \mathrm{H}-8 \times \delta^{18} \mathrm{O}$;

RW: Reservoir water;

--: No record or not measured. 
Table 2 Chemical and isotopic compositions of selected sediment samples from the Datong basin

\begin{tabular}{|c|c|c|c|c|c|c|c|c|c|c|c|c|c|c|c|}
\hline ID & Lithology & $\begin{array}{c}\text { Depth } \\
\mathrm{m}\end{array}$ & ${ }^{87} \mathrm{Sr} /{ }^{86} \mathrm{Sr}$ & $\begin{array}{l}\text { Iodine } \\
\mathrm{mg} / \mathrm{kg}\end{array}$ & $\begin{array}{c}\text { TOC } \\
\%\end{array}$ & $\begin{array}{c}\mathrm{SiO}_{2} \\
\%\end{array}$ & $\begin{array}{c}\mathrm{CaO} \\
\%\end{array}$ & $\begin{array}{c}\mathrm{Al}_{2} \mathrm{O}_{3} \\
\%\end{array}$ & $\begin{array}{c}\mathrm{Fe}_{2} \mathrm{O}_{3} \\
\%\end{array}$ & $\begin{array}{c}\mathrm{MgO} \\
\%\end{array}$ & $\begin{array}{c}\mathrm{Na}_{2} \mathrm{O} \\
\%\end{array}$ & $\begin{array}{c}\mathrm{K}_{2} \mathrm{O} \\
\%\end{array}$ & $\begin{array}{c}\mathrm{MnO} \\
\%\end{array}$ & $\begin{array}{c}\mathrm{P}_{2} \mathrm{O}_{5} \\
\%\end{array}$ & $\begin{array}{c}\mathrm{TiO}_{2} \\
\%\end{array}$ \\
\hline DXZ-02 & Greyish-green silt & 8.5 & 0.71319 & 0.834 & 0.33 & 61.66 & 7.37 & 11.14 & 3.97 & 2.30 & 1.87 & 2.22 & 0.06 & 0.14 & 0.57 \\
\hline DXZ-06 & Green-brown clay & 15.2 & 0.71107 & 1.087 & 5.22 & 28.57 & 29.01 & 7.30 & 3.09 & 2.08 & 0.56 & 1.21 & 0.08 & 0.11 & 0.36 \\
\hline DXZ-17 & Grey silt & 32.6 & 0.71223 & 0.537 & 1.59 & 53.23 & 13.08 & 10.05 & 4.09 & 2.20 & 1.25 & 1.95 & 0.09 & 0.16 & 0.50 \\
\hline DXZ-29 & Dark grey fine sand & 55.6 & 0.71612 & 0.184 & 0.50 & 61.60 & 6.23 & 12.08 & 4.32 & 2.04 & 1.56 & 2.45 & 0.06 & 0.11 & 0.73 \\
\hline DXZ-40 & Grey silt & 72.1 & 0.71472 & 0.596 & 0.06 & 59.98 & 7.45 & 12.30 & 4.42 & 2.42 & 1.73 & 2.41 & 0.1 & 0.16 & 0.61 \\
\hline DXZ-52 & Grey clay & 90 & 0.71299 & 1.463 & 2.10 & 42.54 & 13.29 & 13.48 & 5.73 & 3.58 & 0.77 & 2.38 & 0.11 & 0.19 & 0.59 \\
\hline DXZ-62 & Grey silt & 108 & 0.71524 & 0.322 & 0.06 & 67.26 & 5.03 & 10.88 & 3.61 & 1.79 & 1.76 & 2.20 & 0.05 & 0.09 & 0.66 \\
\hline
\end{tabular}


Table 3 Results of mass transfer calculation using PHREEQC

\begin{tabular}{|c|c|c|}
\hline ID & Solution fractions & \\
\hline DT13-01 & 1 & \\
\hline DT13-04 & 1 & \\
\hline Phase & mole transfer $(\mathrm{mol})$ & \\
\hline Calcite & 0.007492 & $\mathrm{CaCO}_{3}$ \\
\hline $\mathrm{CO}_{2}(\mathrm{~g})$ & 0.01433 & $\mathrm{CO} 2$ \\
\hline $\mathrm{MgX}_{2}$ & -0.00003662 & $\mathrm{MgX}_{2}$ \\
\hline $\mathrm{NaX}$ & 0.01708 & $\mathrm{NaX}$ \\
\hline Quartz & 0.0002374 & $\mathrm{SiO}_{2}$ \\
\hline $\mathrm{CaX}_{2}$ & -0.008505 & $\mathrm{CaX}_{2}$ \\
\hline Gypsum & -0.0008571 & $\mathrm{CaSO}_{4}: 2 \mathrm{H}_{2} \mathrm{O}$ \\
\hline Celestite & $-6.819 \mathrm{E}-07$ & $\mathrm{SrSO}_{4}$ \\
\hline Halite & 0.003092 & $\mathrm{NaCl}$ \\
\hline Kaolinite & 0.0002011 & $\mathrm{Al}_{2} \mathrm{Si}_{2} \mathrm{O}_{5}(\mathrm{OH})_{4}$ \\
\hline Illite & -0.0001749 & $\mathrm{~K}_{0.6} \mathrm{Mg}_{0.25} \mathrm{Al}_{2.3} \mathrm{Si}_{3.5} \mathrm{O}_{10}(\mathrm{OH})_{2}$ \\
\hline
\end{tabular}

Negative values mean phase removal from groundwater, while positive means phase dissolution. 